\title{
Essentials Oils from Brazilian Eugenia and Syzygium Species and Their Biological Activities
}

\author{
Jamile S. da Costa ${ }^{1}$, Ellen de Nazaré S. da Cruz ${ }^{2}$, William N. Setzer ${ }^{3,4} \oplus$, \\ Joyce Kelly do R. da Silva ${ }^{5}$, José Guilherme S. Maia ${ }^{1,6}{ }^{\mathbb{D}}$ and Pablo Luis B. Figueiredo ${ }^{7, *}$ \\ 1 Programa de Pós-Graduação em Ciências Farmacêuticas, Universidade Federal do Pará, \\ Belém 66075-900, Brazil; jamile.s.costa@hotmail.com (J.S.d.C.); gmaia@ufpa.br (J.G.S.M.) \\ 2 Programa Institucional de Bolsas de Iniciação Científica, Universidade Federal do Pará, \\ Belém 66075-900, Brazil; ellen.cruz@icen.ufpa.br \\ 3 Department of Chemistry, University of Alabama in Huntsville, Huntsville, AL 35899, USA; \\ wsetzer@chemistry.uah.edu \\ 4 Aromatic Plant Research Center, 230 N 1200 E, Suite 100, Lehi, UT 84043, USA \\ 5 Programa de Pós-Graduação em Química, Universidade Federal do Pará, Belém 66075-900, PA, Brazil; \\ joycekellys@ufpa.br \\ 6 Programa de Pós-Graduação em Química, Universidade Federal do Maranhão, São Luís 64080-040, Brazil \\ 7 Departamento de Ciências Naturais, Universidade do Estado do Pará, Belém 66050-540, Brazil \\ * Correspondence: pablo.figueiredo@uepa.br
}

Received: 2 July 2020; Accepted: 30 July 2020; Published: 6 August 2020

\begin{abstract}
The Eugenia and Syzygium genera include approximately 1000 and 1800 species, respectively, and both belong to the Myrtaceae. Their species present economic and medicinal importance and pharmacological properties. Due to their chemical diversity and biological activity, we are reporting the essential oils of 48 species of these two genera, which grow in South America and found mainly in Brazil. Chemically, a total of 127 oil samples have been described and displayed a higher intraspecific and interspecific diversity for both Eugenia spp. and Syzygium spp., according to the site of collection or seasonality. The main volatile compounds were sesquiterpene hydrocarbons and oxygenated sesquiterpenes, mainly with caryophyllane and germacrane skeletons and monoterpenes of mostly the pinane type. The oils presented many biological activities, especially antimicrobial (antifungal and antibacterial), anticholinesterase, anticancer (breast, gastric, melanoma, prostate), antiprotozoal (Leishmania spp.), antioxidant, acaricidal, antinociceptive and anti-inflammatory. These studies can contribute to the rational and economic exploration of Eugenia and Syzygium species once they have been identified as potent natural and alternative sources to the production of new herbal medicines.
\end{abstract}

Keywords: Eugenia spp; Syzygium spp; Myrtaceae; essential oil variability; mono- and sequiterpenes; biological properties

\section{Introduction}

From the latter 19th century through the second half of the 20th century, Syzygium species were included in the Eugenia genus. However, anatomical and morphological analyses provided evidence that these genera were not closely linked, and a distinction between individuals belonging to these two genera has been attributed [1]. Eugenia and Syzygium genera belong to the Myrtaceae family, included in the Myrtales order, Rosidae clade, and Malvidae subclade [2]. In recent studies, these genera have been classified into subgenera; Eugenia includes Eugenia, Hexachlamys, and Pseudeugenia subgenera [3], while the Syzygium genus encompasses Syzygium, Acmena, Sequestratum, Perikion, Anetholea, and Wesa subgenera [4]. 
Eugenia L. has approximately 1000 species, occurring in Central and South America, and few in the African continent [5]. They can be shrubs or small trees, twigs glabrous or pubescent when young. Leaves are opposite, petiolate; lamina gland-dotted, intramarginal vein visible. Inflorescence is axillary; solitary flowers, fascicled or rarely in triads; pubescent peduncles; pubescent bracts, persistent. Flowers are 4-merous, buds usually turbinate; rounded sepals, sparsely pubescent; petals \pm orbicular, gland-dotted, and ciliate margins-stamens in multiple whorls on a broad staminal disc; ovary 2-locular, ovules several to many, radiating from a centrally-located axile placenta; style about as long as the stamens or slightly longer; stigma not dilated. Fruits are succulent berries; sepals persistent; seed 1-2, cotyledons of uniform texture, partly fused [6].

Eugenia species have great ecological relevance because their fruits are sources of food for birds, mammals, and reptiles [7]. Moreover, this genus stands out due to the commercial exploitation of edible fruits, wood, essential oils, and plants for ornamental purposes, and its pharmacological potential [8,9]. For example, infusions and teas of leaves, fruits, and trunk bark of Eugenia brasiliensis are used in Amazon folk medicine to treat stomach diseases, as an antirheumatic, anti-inflammatory, antidiarrheal, and diuretic. In contrast, decoctions of twigs of Eugenia supraaxillaris (syn. Eugenia axillaris) are used as antirheumatic and bathing by women after childbirth [10].

Syzygium Gaertn. has 1800 species [11], mainly found in the southern and Southeast Asia, southern China, Australia, Malaysia and New Caledonia, and some in East Africa, Madagascar, Mascarenhas Islands, southwest Pacific islands, Taiwan, and southern Japan [12]. There are only four species occurring in South America: Syzygium aqueum (syn. Eugenia aquea, Jambosa aquea), S. cumini (syn. E. jambolana, Syzygium jambolanum), S. jambos (Eugenia jambos, E. monantha, Syzygium merrillii, S. monanthum), and S. malaccense [13].

Although Syzygium species are not native to the Americas, their species are well spread throughout South America in afforestation and decoration. Syzygium cumini and S. malaccense are two of the most widespread and popularly known exotic species throughout the Brazilian territory and commonly found in indigenous villages in the sub-spontaneous state amid natural vegetation [14].

Syzygium species can be trees, with thick, granular bark; twigs usually glabrous. Leaves are opposite, entire, penninerved, usually gland-dotted; lateral nerves united, forming a clear or faint intramarginal vein. Flowers are bisexual, in terminal or axillary corymbose cymes or panicles; calyx tube hemispherical, globose, or turbinate, tube produced above the summit of the ovary, lobes four or five, ovate to suborbicular, imbricate; petals four or five, orbicular, pellucid-glandular; stamens numerous, filaments inflexed in bud; staminal disc broad or absent; anthers globose; ovary inferior, two-celled; ovules few to several in each cell; style 1, subulate, stigma simple. The fruit is a berry, one-celled; seeds few [15].

Syzygium is one of the most common tree genera in the forest ecosystem, presenting nectariferous flowers, often in mass and typically fleshy fruits; it is used as food by birds, insects, and small and large mammals [1,12]. Its species present economic and medicinal importance [16], and pharmacological proprieties being a potential source for pharmacochemistry studies $[17,18]$. Traditional communities use the infusions and decoction leaves of Syzygium cumini and S. aqueum to treat diabetes, and stomach pains and dysentery, respectively $[19,20]$.

Chemometrics analysis, such as Principal cluster analysis (PCA) and Hierarchical cluster analysis (HCA), is the most used method to group essential oils from many samples. PCA is often the first step in multivariate data analysis. The score plot is a graphical representation that provides information about relationships between samples and chemical compounds. In turn, HCA is a significant pattern recognition technique used as a preliminary evaluation of a given data set. In HCA, samples are grouped based on information that describes their relationship by similarities, such as distance and correlation. HCA is plotted in branched structures with a defined hierarchy (called dendrogram), which permits a qualitative visualization (in two-dimensional space) of grouping among samples [21]. 
Due to the chemical and biological importance of Eugenia and Syzygium species, in this review, we report 127 chemical compositions of 48 species of these two genera growing in South America (Figure 1) and their biological activities.

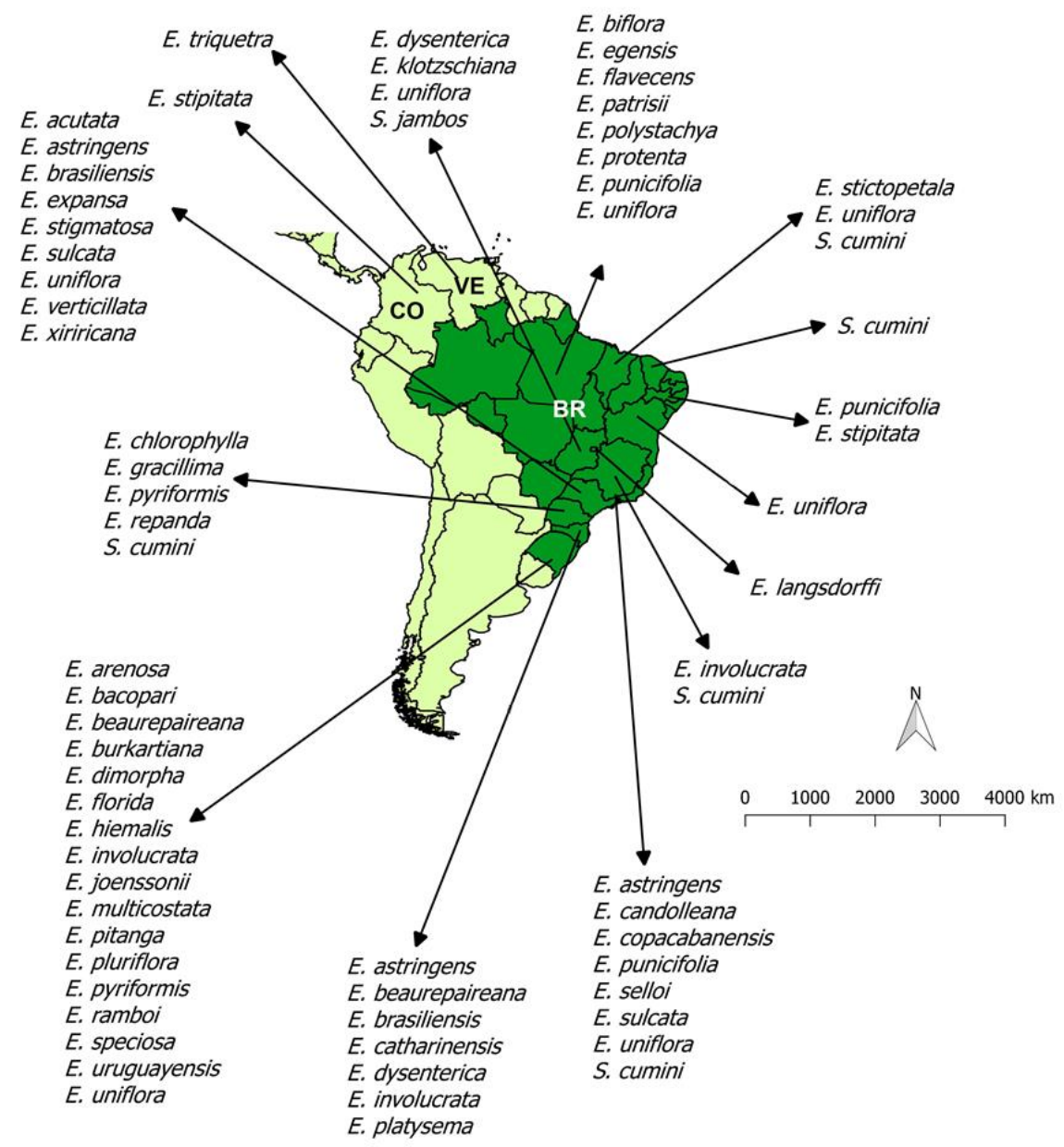

Figure 1. Geographical distribution in South America of Eugenia and Syzygium specimens based on their essential oil studies. This map was built by the authors using the information of the plant occurrence, available in each bibliographic reference. Abbreviation list: BR: Brazil, VE: Venezuela, CO: Colombia.

\section{Bibliographic Search Criteria}

The bibliographic research was performed using the databases Google Scholar, Pubmed, Science Direct, Medline, and Scopus. The keywords applied were "Eugenia", "Syzygium" and "essential oils"; and "volatile compounds", and "essential oils". Some unusual or incorrect botanical names were updated based on The Plant List" (http://www.theplantlist.org/).

\section{Volatile Profiles}

Eugenia essential oils are characterized by intra- and interspecific chemical diversity, with the predominance of cyclic sesquiterpenes, follow by monoterpenes, and without phenylpropanoids as the main compound (See Appendices A and B) [22]. However, dimethylxanthoxylin (73.2 and 83.0\%), an acetophenone derivative, was identified by GC-MS and NMR techniques as the major constituent in EOs of two specimens of E. protenta McVaugh collected in Santarém Novo, western Pará state located in the Brazilian Amazon [23].

Some essential oils of Eugenia species have shown great interspecific chemical variation. For example, Eugenia protenta EOs from Pará state (Brazil) occurring at three chemical profiles rich in the cyclic sesquiterpenes with eudesmane, elemane, and germacrane skeletons as selin-11-en-4 $\alpha$-ol 
(14.4-18.3\%) and $\beta$-elemene (12.3-18.3\%) (profile I); germacrene D (15.1-15.6\%), bicyclogermacrene (5.8-11.8\%), $\delta$-elemene (8.5\%), and $\beta$-elemene (9.2-12.8\%) (profile II); or characterized by the presence of dimethylxanthoxylin (73.2-83.0\%) (profile III) [23]. E. biflora (L.) DC. EOs from Brazil were classified in four chemical profiles as follows: caryophyllane profile, with a significant content of the sesquiterpenes (E)-caryophyllene (9.8-16.8\%) and caryophyllene oxide (20.5-28.6\%); cadinane profile, characterized by the presence of $\alpha$-cadinol (14.7\%); aromadendrane profile, with the predominance of the sesquiterpenes globulol (9.8\%), germacrene B (7.9\%) [24]; and pinane profile with $\beta$-pinene (27.8\%) and $\alpha$-pinene $(27.3 \%)$ as main constituents [25].

Oils of E. astringens Cambess. (syn. E. umbelliflora) present two chemical profiles, three specimens collected in Rio de Janeiro and São Paulo states (Brazilian southeast) were shown to be rich in $\alpha$-pinene (15.8-34.5\%) and $\beta$-pinene (11.0-34.1\%) [26-28]. The specimen from Santa Catarina (Brazil southern) was rich in viridiflorol (17.7\%), followed by $\beta-(13.2 \%)$ and $\alpha$-pinene (11.2\%) [29]. E. beaurepairiana oils from Santa Catarina state (Brazil southern) showed high amounts of cyclic sesquiterpene hydrocarbons with germacrane/caryophyllane/cadinane skeleton such as bicyclogermacrene (7.2-14.3\%), germacrene $\mathrm{D}(1.6-8.6 \%),(E)$-caryophyllene (6.4-8.0\%), and $\delta$-cadinene $(4.9-7.2 \%)$ [30,31].

Eugenia brasiliensis Lam. leaf oils collected in the south and southeast Brazil displayed the occurrence of three chemical profiles. Its oils can be rich in bicyclic monoterpenes as $\beta$-pinene (10.4\%) and $\alpha$-pinene $(10.3 \%$ ) [32]; or $\alpha$-pinene (18.8-35.5\%), $\beta$-pinene (11.0-14.4\%), followed by 1,8 -cineol (9.6-28.2\%) [33]; and rich in a mixture of oxygenated sesquiterpenes as spathulenol (12.7\%), $\tau$-cadinol $(8.7 \%)$ and viridiflorol (7.1\%) [29]. In addition, E. brasiliensis fruits showed different volatile profiles according to their genotypic variety. The oils extracted from the yellow variety showed as the main compound $\alpha$-pinene $(15.4 \%)$, myrcene $(10.7 \%)$, and $\alpha$-terpineol $(10.2 \%)$, while oils from purple variety presented caryophyllene oxide (22.2\%) and $\alpha$-cadinol $(10.4 \%)$ [33].

A stems oil of Eugenia chlorophylla O.Berg from Paraná state, Brazil, was rich in oxygenated sesquiterpenes (83.4\%), characterized by caryophyllene oxide (17.2\%), globulol (16.5\%), $\tau$-muurolol $(16.8 \%), \alpha$-cadinol (12.1\%) and 1-epi-cubenol (10.9\%). At the same time, it leaves oil composition at the vegetative, and flowering stages had only small quantitative differences, with globulol as the main compound at the vegetative (22.3\%) and flowering (18.9\%) stages. Additionally, the flowers' oil was characterized by the predominance of sesquiterpene hydrocarbons (33.2\%), such as (E)-caryophyllene (12.8\%), $\alpha$-cadinol (10.1\%), caryophyllene oxide (8.9\%) and $\tau$-murolol (8.5\%) [34].

Essential oils of E. dysenterica (Mart.) DC. leaves from central and southern regions of Brazil displayed the sesquiterpene $(E)$-caryophyllene as the main compound $(14.8 \%$ and $24.0 \%$, respectively). The minority compounds were monoterpenes with pinane ( $\beta$-pinene and $\alpha$-pinene), menthane ( $\alpha$-terpineol and limonene), caryophyllane ( $\alpha$-humulene and caryophyllene oxide), and cadinane skeletons ( $\delta$-cadinene, $\alpha$-copaene), displaying variability in their amounts $[35,36]$.

The oils of E. flavescens DC. were rich in sesquiterpenes with germacrane and bisabolane skeletons such as germacrene D (14.5\%) and bicyclogermacrene (11.7\%) [25], or $\beta$-bisabolene $(34.7 \%)$ and (E)- $\gamma$-bisabolene (35.0\%) [37]. Additionally, oils from E. involucrata DC. leaves displayed two chemical profiles rich in sesquiterpenes with germacrane skeleton. The first one rich in $\beta$-elemene $(42.4 \%)$ and bicyclogermacrene (23.0\%) [38], and the second rich in spathulenol (21.4\%) and bicyclogermacrene (19.3\%) [39]. Additionally, the oils of E. involucrata fruits presented a mixture of the sesquiterpenes (E)-caryophyllene (10.1\%) and spathulenol (7.8\%) as its primary constituents [40].

The moisture of plant material can influence in the EOs yield and composition. Leaves of E. klotzschiana O.Berg dried by three different processes (in natura, at room temperature, and drying by forced air circulation) showed qualitative and quantitative variations in their oil constituents. The main compounds were $\alpha$-copaene (1.7-10.6\%), $\beta$-bisabolene (1.9-17.4\%), trans- $\alpha$-bergamotene $(0.0-10.1 \%)$, spathulenol (7.2-10.9\%) and germacrene D (2.4-13.3\%). Besides, there was a clear difference between the oil compositions from its leaves and flowers, which this last was rich in trans- $\alpha$-bergamotene (29.9\%) [41]. 
The EOs of leaves of E. langsdorffii O.Berg presented epi-longipinanol (13.6\%), $\gamma$-eudesmol (12.3\%), limonene (11.8\%), and 10-epi- $\gamma$-eudesmol (10.6\%) as the major constituents, while their fruits showed 10-epi- $\gamma$-eudesmol (35.7\%), 1,10-di-epi-cubenol (15.6\%) [42].

The leaf oil of E. patrisii Vahl was characterized by presence of cyclic sesquiterpenes with cadinane and caryophyllane skeletons including trans-cadin-1,4-diene (16.5\%), trans-muurola-3,5-diene (13.3\%), (E)-caryophyllene (11.1\%) and $\alpha$-cubebene (9.8\%) [25]. However, its aerial parts (leaves and fine stems) had a mixture of acyclic and cyclic oxygenated sesquiterpenes as $(2 E, 6 E)$-farnesol $(34.5 \%)$, (2E,6Z)-farnesol (23.2\%), caryophylla-4(12)-8(13)-dien-5 $\beta$-ol (15.6\%) as major constituents [37].

Different chemical oil profiles of E. punicifolia (Kunth) DC. were found. Specimens collected in Brazilian northeast showed linalool (44.0-61.2\%), (E)-caryophyllene (16.2-22.7\%), and $\alpha$-terpineol $(6.7-8.8 \%)$ as the main compounds [43]. Specimens sampled in Brazilian Amazon presented the sesquiterpene hydrocarbons (E)-caryophyllene (9.9\%), bicyclogermacrene $(8.7 \%)$, germacrene D $(5.4 \%)$ and the monoterpene $(E)-\beta$-ocimene $(5.5 \%)$ as their primary constituents [25]. Additionally, in another plant sample from Brazilian southeast predominated sesquiterpenes with cadinane/germacrane skeleton as $\alpha$-cadinol (10.6\%), 10-epi- $\gamma$-eudesmol (10.2\%), paradisiol (9.0\%), and 7-epi- $\alpha$-selinene (6.8\%) [28].

Essential oil from leaves of E. pyriformis Cambess. collected in southern Brazil showed two chemical profiles: The first one (1) showing sesquiterpenes with cadinane/germacrane-type skeletons as $\alpha$-cadinol (14.0\%), $\delta$-cadinene (12.4\%), $\tau$-cadinol (11.9\%), and bicyclogermacrene (10.2\%) [30]; and the second (2) presenting the monoterpenes $\beta$-pinene $(0.2-25.7 \%)$, limonene $(0.2-22.0 \%)$, and 1,8 -cineole $(0.6-14.7 \%)$, with pinane and menthane-type skeletons, and the sesquiterpene caryophyllene oxide (3.9-21.3\%) with a caryophyllane-type skeleton [44]. Additionally, flowers EO was characterized by caryophyllane/cadinane sesquiterpene-types, as $(E)$-caryophyllene $(22.8 \%)$, germacrene D $(15.3 \%)$, bicyclogermacrene (8.4\%), and $\alpha$-cadinol (7.2\%) [44]. Additionally, fruits oil of E. pyriformis showed caryophyllene oxide $(16.2 \%)$, limonene $(12.4 \%), \alpha$-terpineol $(5.4 \%), \alpha$-cadinol $(5.4 \%)$ as the main compounds [44].

Leaf oils of E. sulcata Spring ex Mart. from Brazil may be characterized by two different chemical profiles: the first one (1) presented $(E)$-caryophyllene (15.0-24.6\%), $\alpha$-pinene (17.2-34.2\%), and $\beta$-pinene $(1.7-10.9 \%)[32,45,46]$, and the second (2) showed 1,8-cineole $(19.0 \%), \alpha$-pinene $(16.9 \%)$, and $\beta$-pinene $(14.5 \%)$ [28]. Another sample of fine stems oil was rich in (E)-caryophyllene (18.8\%), spathulenol $(8.8 \%)$, and trans-calamenene $(7.0 \%)$ with minor amounts of $\alpha$ - and $\beta$-pinene [46].

There is a significant chemical variability on the essential oils of Eugenia uniflora L, the most studied Eugenia species [22], with the occurrence of about nine chemotypes, rich in cyclic oxygenated sesquiterpenes, with a germacrane-type skeleton, as the curzerene (thermally produced in situ during the oil processing) [47-50], atractylone [51,52], selina-1,3,7(11)-trien-8-one and selina-1,3,7(11)-trien-8-one epoxide [48,49,53,54], germacrone [55,56], and in association with other cyclic sesquiterpene hydrocarbons [48,49,51,56-58].

Although various Eugenia species and specimens have been widely studied concerning their leaf essential oil compositions, about 26 species were sampled only once to furnish their oil compositions. These plant samples exist mainly in Brazil, and the species that included monoterpene hydrocarbons preferably were E. dimorpha O.Berg ( $\alpha$-pinene, 22.4\%) [59], E. multicostata D.Legrand ( $\alpha$-pinene, 16.1\% and spathulenol 10.7\%) [32], E. speciosa Cambess. ( $\alpha$-pinene, $47.3 \%$ and limonene, $23.0 \%$ ) [32], and E. uruguayensis Cambess. ( $\alpha$-pinene, 23.5\% and $\beta$-pinene, 11.8\%) [27]; and that included sesquiterpene hydrocarbons were E. acutata Miq. (E)-caryophyllene, 26.93\%) [60], E. bacopari D.Legrand ( $\delta$-cadinene, $15.8 \%$ and aromadendrene, 12.2\%) [59], E. burkartiana (D.Legrand) D.Legrand (bicyclogermacrene, 14.2\%, germacrene D, 8.8\% and (E)-caryophyllene, 7.8\%) [59], E. florida DC. (E-caryophyllene, $14.5 \%$ and $\beta$-elemene, 1.8\%) [61], E. hiemalis Cambess. (bicyclogermacrene, 37.7\%) [62], E. pitanga (O.Berg) Nied. (germacrene D, 29.3\% and bicyclogermacrene, 22.4\%) [32], E. platysema O.Berg ( $\beta$-selinene, 17.9\%, allo-aromadendrene, $12.6 \%$ and 7 -epi- $\alpha$-selinene, 10.4\%) [27], E. ramboi D.Legrand ( $\beta$-elemene, 10.6\%, bicyclogermacrene, 9.7\% and (E)-caryophyllene, 6.2\%) [27], E. repanda O.Berg ((E)-caryophyllene, $16.3 \%, \alpha$-humulene, 10.2\% and bicyclogermacrene, 9.4\%) [61], E. stictopetala 
Mart. ex DC. ( $\gamma$-elemene, $17.48 \%$, (E)-caryophyllene, $16.46 \%$ and bicyclogermacrene, $8.11 \%$ ) [63], and E. polystachya rich. (germacrene D, 18.4\%, ishwarane, $15.7 \%$ and 7 -epi- $\alpha$-selinene, $7.5 \%$ ) [37]. Moreover, eight species were found to have oxygenated sesquiterpenes as the major constituents: E. candolleana DC. (1-epi-cubenol, 77.59\%) [60]. E. egensis DC. (5-hydroxy-trans-calamenene, 35.8\%) [37], E. expansa Spring ex Mart. (spathulenol, 12.1\% and (E)-caryophyllene, 9.2\%) [32], E. gracillima (globulol, 8.7\%, viridiflorene, 6.9\%, epi-globulol, 6.8\%, and spathulenol, 5.9\%) [59], E. joenssonii Kausel (5-epi-paradisiol, 8.4\%, $\delta$-selinene 7.9\%, and $\beta$-selinene, 7.2\%) [59]; E. pluriflora DC. ((E)-nerolidol, $24.6 \%$ and $\alpha$-pinene, 24.0\%) [27], E. verticillata (Vell.) Angely (valerianol, 28.1\% and 10-epi- $\gamma$-eudesmol, 12.6\%) [64], and E. xiriricana Mattos (spathulenol, 15.4\% and $\beta$-pinene, 14.1\%) [32]. In addition, three species presented other constituents such as esters, carboxylic acid, and oxygenated monoterpenes as main compounds. They were E. catharinensis D.Legrand (ethyl palmitate, $10.5 \%$; trans- $\alpha$-bergamotene, 6.5\%; and $\beta$-selinene, 5.9\%) [59], E. stigmatosa DC. (physeteric acid, 90.5\%) [62], and E. triquetra O.Berg (from Venezuela) (linalool, 17.5\%, limonene, 16.9\%, $\alpha$-pinene, 11.6\%, and $\beta$-pinene, $8.7 \%$ ) [65].

Chemical profiles of oils from Syzygium species growing in South America are poorly described in the literature. We found seven Syzygium cumini accessions (specimens) growing in Brazil. It is known that the collection site and habitat affect the chemical composition of essential oils. The oils of S. cumini (L.) Skeels (syn. Eugenia cumini and E. jambolana) collected in Brazil (Ceará, Maranhão, and Rio de Janeiro states) showed $\alpha$-pinene (22.2-48.0\%) as the main constituent [66-69], while another oil of S. cumini collected in Minas Gerais state, Brazil, showed $\alpha$-humulene $(25.2 \%)$ and $(E)$-caryophyllene $(16.0 \%)$ as the predominant compounds [70].

\section{Seasonal Variation of Oil Composition}

Some studies have shown variation in the chemical composition and yield of EOs of Eugenia and Syzygium affected by seasonality. Samples of fresh leaves of E. astringens (syn. Eugenia rotundifolia), with Brazil's occurrence, were collected every three months. The oil was mainly composed of cyclic monoterpene and sesquiterpene hydrocarbons, as $\alpha$-pinene (19.7-34.4\%), $\beta$-pinene (20.6-34.1\%), and $(E)$-caryophyllene (3.6-11.7\%). The rain precipitation data displayed a significant positive and negative correlation between the $(E)$-caryophyllene and $\alpha$-pinene content, respectively [26].

Two oil profiles of $E$. brasiliensis were monitored according to their seasonal and circadian variations. A specimen collected in Santa Catarina state, Brazil, showed $\alpha$-pinene (1.77-15.94\%), $\beta$-pinene (2.98-11.24\%), spathulenol (8.10-18.17\%), 1-epi-cubenol (4.83-7.46\%), and $\tau$-cadinol $(10.38-15.30 \%)$ as main volatile compounds. Spathulenol was the most abundant in the spring $(16.02 \%)$ and summer $(18.17 \%)$, $\tau$-cadinol in the autumn $(12.83 \%)$, and $\alpha$-pinene $(15.94 \%)$ in the winter [71]. The oil of the specimen collected in São Paulo state, Brazil, presented spathulenol (7.0-18.0\%), trans- $\alpha$-bergamotene (2.6-19.0\%), $\alpha$-thujene (4.0-11.5\%), and $\beta$-selinene (2.3-8.5\%) as primary constituents, with a significant content variation on the seasonality study. The monoterpenes amount was higher in July, September, and November, mainly for $\alpha$-thujene (10-11\%) and $\beta$-pinene $(6-8 \%)$, which were detected in low proportion in the other collection months. On the other hand, the number of oxygenated sesquiterpenes increased from January (45.0\%) to May (56.2\%) [72].

The oil composition of leaves of E. pyriformis was monthly monitored and showed as main compounds the monoterpenes $\beta$-pinene $(0.0-25.7 \%)$, limonene $(0.2-22.0 \%)$, and 1,8-cineole (0.6-14.7\%), followed by the sesquiterpene, caryophyllene oxide (3.9-21.3\%). During the annual study, the monoterpenes were predominant in nine months, excepting April, October, and December, where the sesquiterpenes showed concentrations higher than $70 \%$. The monoterpene hydrocarbon $\beta$-pinene was the principal constituent in January $(25.0 \%)$, presented meaningful content in other months, but it was absent in October [44].

Two different leaf oil profiles of E. uniflora were monitored during the year seasonal changes. The oil with profiles rich in curzerene (34.0-53.1\%) [73], and selin-1,3,7(11)-trien-8-one (43.0\%) plus selin-1,3,7(11)-trien-8-one epoxide (20.0-29.0\%) [54] have a clear seasonal influence, however these profiles did not interconvert themselves. The curzerene content showed no significant difference 
between the dry (42.7\%) and rainy (40.8\%) seasons, presenting a high level of similarity by HCA analysis [73]. On the other hand, the selin-1,3,7(11)-trien-8-one plus selin-1,3,7(11)-trien-8-one epoxide profile showed a separation into two different clusters for the oils: Cluster I included samples collected in the dry season, and it was characterized by the highest percentage of spathulenol $(10.0 \%)$ and caryophyllene oxide (4.0\%). Cluster II grouped samples collected in the rainy season showed selina-1,3,7(11)-trien-8-one epoxide (29\%) as the principal constituent. Additionally, another two subclusters separated the rainy sampling months. The first one characterized by a high percentage of selina-1,3,7(11)-trien-8-one (46.4\%), and the second that was rich in selina-1,3,7(11)-trien-8-one epoxide $(37.0 \%)$ [54].

The leaf oils of Syzygium jambos (L.) Alston, collected in different year seasons, showed an environmental influence due to the foliar nutrients $(\mathrm{N}, \mathrm{Mn}, \mathrm{Co}, \mathrm{Fe}, \mathrm{S}$, and $\mathrm{Mg})$, and soil nutrients $(\mathrm{Na}$, $\mathrm{Al}, \mathrm{S}$ and $\mathrm{H}^{+}$, and $\left.\mathrm{Al}\right)$. The main compounds were $(E)$-caryophyllene $(0-10.86 \%), \alpha$-humulene $(0.0-7.1 \%)$, $\alpha$-zingiberene $(0.97-17.73 \%)$, caryophyllenyl alcohol (1.48-17.14\%), caryolan-8-ol $(0.0-10.75 \%)$, caryophyllene oxide $(0.0-5.05 \%)$, thujopsan-2- $\alpha$-ol (1.01-12.19\%), and heneicosane (1.73-18.0\%) [74].

\section{Differences in Oil Composition and Extractions Methods}

Differences in EO's yields and chemical composition may be associated with the extraction technique employed and its conditions. Some studies compared the extraction methods and reported their influence in yields and chemical compositions of oils [74]. The leaf oil of E. involucrata collected in Rio de Janeiro (Brazil) was rich in $\beta$-elemene $(41.8 \%)$, bicyclogermacrene $(28.4 \%)$ and $(E)$-caryophyllene (6.7\%) when extracted by $\mathrm{CO}_{2}$ supercritical fluid. However, the oil showed quantitative variations of $\beta$-elemene $(42.4 \%)$, bicyclogermacrene $(23.0 \%)$, and $(E)$-caryophyllene $(13.4 \%)$ when extracted by hydrodistillation [37].

\section{Biological Activities}

\subsection{Antibacterial and Antifungal Activity}

In the last years, antimicrobial resistance to antibiotics has been increasing due to the adaptive evolution of bacteria and fungi. For this reason, research focused on the potential of new antimicrobial agents based on natural products has been explored, particularly the essential oils [75].

Several published works have reported the potential of Eugenia and Syzygium EOs against Gram-positive and Gram-negative bacteria. Among the Gram-positive strains, Staphylococcus aureus, S. mitis, S. sanguinis, S. epidermis, S. saprophyticus, Listeria monocytogenes, Streptococcus equi, S. mutans, S. sobrinus, Bacillus cereus, B. subtilis, Enterococcus faecalis, Mycobacterium bovis, Kocuria rhizophila were evaluated. Concerning the Gram-negative strains, Prevotella nigrescens, Porphyromonas gingivalis, Escherichia coli, Pseudomonas aeruginosa, Enterobacter aerogenes, Salmonella spp., S. enteritidis, S. typhimurium, and Neisseria gonorrhoeae were included.

Essential oils from Eugenia astringens, E. beaurepaireana, E. brasiliensis, E. chlorophylla, E. stipitata, E. uniflora, and Syzygium cumini were tested against Staphylococcus aureus strains and showed minimal inhibitory concentrations (MICs) ranged from 119.2 to $56,000 \mu \mathrm{g} / \mathrm{mL}$ [29,34,57,68,76,77].

Eugenia uniflora oils showed low activity when tested against Staphylococcus epidermis (MIC $7500 \mu \mathrm{g} / \mathrm{mL}$ ) and S. equi (MIC $7500 \mu \mathrm{g} / \mathrm{mL}$ ) [51]. The oils of E. involucrata displayed activity against Streptococcus mitis (MIC $400 \mu \mathrm{g} / \mathrm{mL}$ ), S. sanguinis (MIC $400 \mu \mathrm{g} / \mathrm{mL}$ ), Prevotella nigrescens (MIC $100 \mu \mathrm{g} / \mathrm{mL}$ ), and Porphyromonas gingivalis (MIC $100 \mu \mathrm{g} / \mathrm{mL}$ ) [39]. The oils of E. astringens (MIC $477 \mu \mathrm{g} / \mathrm{mL}$ ), E. beaurepaireana (MIC $556.6 \mu \mathrm{g} / \mathrm{mL}$ ), E. brasiliensis (MIC 624.9-1000 $\mu \mathrm{g} / \mathrm{mL}$ ) and E. stipitata (inhibition halo $11 \mathrm{~mm}$, tetracycline standard $7 \mathrm{~mm}$ ) presented antibacterial activity against Escherichia coli $[29,68,71,77]$. The oil of E. dysenterica showed activity against Cryptococcus neoformans var. neoformans (MIC $250 \mu \mathrm{g} / \mathrm{mL}$ ) and C. neoformans var. gattii (MIC $250 \mu \mathrm{g} / \mathrm{mL}$ ) [35]. Oils of E. astringens (MIC $470 \mu \mathrm{g} / \mathrm{mL}$ ), E. beaurepaireana (MIC $270 \mu \mathrm{g} / \mathrm{mL}$ ), E. brasiliensis (MIC 500-1000 $\mu \mathrm{g} / \mathrm{mL}$ ), E. stipitata 
(inhibition halo $11 \mathrm{~mm}$, tetracycline standard $7 \mathrm{~mm}$ ) and E. uniflora (MIC $625 \mu \mathrm{g} / \mathrm{mL}$ ) showed activity against Pseudomonas aeruginosa $[29,67,71,76,77]$.

Additionally, oils of Eugenia uniflora presented a moderate activity against Listeria monocytogenes (MIC $1040 \mu \mathrm{g} / \mathrm{mL}$ ) [57], differently of E. stipitata oil (inhibition halo $12 \mathrm{~mm}$, tetracycline standard that showed no inhibition) [77]. Furthermore, the oils of Eugenia uniflora showed activity against Streptococcus mutans (MIC $50 \mu \mathrm{g} / \mathrm{mL}$ ), S. sobrinus (MIC $50 \mu \mathrm{g} / \mathrm{mL}$ ), and Kocuria rhizophila (MIC $500 \mu \mathrm{g} / \mathrm{mL}$ ) [34]. However, it was not active against Enterobacter aerogenes (MIC 3.125\%) and Salmonella typhimurium (MIC 3.125\%) [78]. With respect to antifungal activity, the oils of E. uniflora displayed fungicidal activity against Paracoccidioides brasiliensis with MICs between 62.5 and $500 \mu \mathrm{g} / \mathrm{mL}$ [49]; and many Candida species, as Candida dubliniensis (MIC $230 \mu \mathrm{g} / \mathrm{mL}$ ), C. tropicalis (MIC $900 \mu \mathrm{g} / \mathrm{mL}$ ), C. albicans (MIC $1800 \mu \mathrm{g} / \mathrm{mL}$ ), C. glabrata (MIC $930 \mu \mathrm{g} / \mathrm{mL}$ ), C. parapsilosis (MIC $3750 \mu \mathrm{g} / \mathrm{mL}$ ), C. grubii serotype A (MIC $450 \mu \mathrm{g} / \mathrm{mL}$ ), C. gattii serotype C (MIC $1800 \mu \mathrm{g} / \mathrm{mL}$ ), C. gattii serotype B (MIC $220 \mu \mathrm{g} / \mathrm{mL}$ ), C. neoformans serotype D (MIC $110 \mu \mathrm{g} / \mathrm{mL}$ ), C. lipolytica (MIC $93.7 \mu \mathrm{g} / \mathrm{mL}$ ), and C. guilliermondii (MIC $109.4 \mu \mathrm{g} / \mathrm{mL}$ ) [51,57]. Additionally, the oils of E. chlorophylla showed activity against Candida albicans (MIC $500 \mu \mathrm{g} / \mathrm{mL}$ ) and C. tropicalis (MIC $500 \mu \mathrm{g} / \mathrm{mL}$ ) [34].

\subsection{Acetylcholinesterase Inhibition}

Acetylcholinesterase (AChE) acts in the final step of the nervous impulse transmission by hydrolysis of acetylcholine (ACh), a neurotransmitter. AChE inhibitors reduce the ACh level in the brain and increase its concentration in the synapses [79]. In this sense, these inhibitors represent major compounds approved for clinical use in the symptomatic management of Alzheimer's disease and other neurodegenerative disorders [80]. In recent years, natural compounds from essential oils have shown a high anticholinesterase potential [79].

There are few studies on Eugenia and Syzygium oils with this focus in South America. The essential oil of Eugenia sucata, collected in Rio de Janeiro, Brazil, rich in (E)-caryophyllene (24.6\%), showed antiacetylcholinesterase activity $\left(\mathrm{IC}_{50} 4.66 \mu \mathrm{g} / \mathrm{mL}\right.$ ) by the Elman colorimetric method when compared to physostigmine $\left(\mathrm{IC}_{50} 0.59 \mu \mathrm{g} / \mathrm{mL}\right.$ ), the positive control [46]. Moreover, the oil of E. verticillata (syn. E. riedeliana) from São Paulo (Brazil), rich in valerianol (28.1\%), showed an $\mathrm{IC}_{50}$ of $67.3 \mu \mathrm{g} / \mathrm{mL}$ [64]. On the other hand, the oil of E. brasiliensis sampled in Santa Catarina, Brazil, with a seasonal variation of $\alpha$-pinene (1.77-15.94\%), $\beta$-pinene (2.98-11.24\%), spathulenol (8.10-18.17\%), 1-epi-cubenol (4.83-7.46\%) and $\tau$-cadinol (10.38-15.30\%), displayed low antiacetylcholinesterase activity $\left(\mathrm{IC}_{50}>1000 \mu \mathrm{g} / \mathrm{mL}\right)$, when compared to the control galanthamine ( $\left.\mathrm{IC}_{50} 6.93 \mu \mathrm{g} / \mathrm{mL}\right)$ [71].

\subsection{Cytotoxic Activity}

The anticancer potential of essential oils has been widely studied, aiming to mitigate the resistance development to multiple drugs and side effects associated with antitumor drugs currently used [81]. Essential oils of E. egensis, E. flavescens, E. patrisii, E. polystachya and E. uniflora showed cytotoxic activity against human cancer cell lines. The main human carcinoma cell lines evaluated were colorectal (HCT-116), gastric (AGP-01), and melanoma (SKMEL-19) [37,48].

The essential oil of E. uniflora, sampled in Brazil, where the selin-1,3,7(11)-trien-8-one, selin-1,3,7(11)-trien-8-one epoxide, and curzerene were the primary constituents, showed high cytotoxic activity against the colorectal (HCT-116), gastric (AGP-01) and melanoma (SKMEL-19) strains, with $\mathrm{IC}_{50}$ values between 8.73 to $16.26 \mu \mathrm{g} / \mathrm{mL}$ [48]. However, another E. uniflora oil chemotypes, where predominated a mixture of caryophyllene oxide, selin-1,3,7(11)-trien-8-one, selin-1,3,7(11)-trien-8-one epoxide, germacrene B, curzerene and (E)-caryophyllene, did not show cytotoxic activity against these cells [48]. Furthermore, oils of E. flavescens, E. patrisii, and E. polystachya, rich in $\gamma$-bisabolene, $(2 E, 6 E)$-farnesol and germacrene $D$, displayed activity against colorectal carcinoma (HCT-116) with $\mathrm{IC}_{50}$ values of $13.9,16.4$ and $10.3 \mu \mathrm{g} / \mathrm{mL}$, respectively. On the other hand, the oil of E. egensis, rich in 5-hydroxy-cis-calemenene (35.8\%) did not show cytotoxic activity against this cell line $\left(\mathrm{IC}_{50}>25 \mu \mathrm{g} / \mathrm{mL}\right)$ [37]. 


\subsection{Antiprotozoal Activity}

The protozoal or parasitic diseases induce significant morbidity and mortality, being endemic to developing countries. Thus, affordable drugs have serious side effects, high cost, and low effectiveness. Moreover, there is an increased need to expand the investigations for new drug development [82]. In this way, essential oils could be promising sources of antiprotozoal agents, opening perspectives to discover more effective drugs of vegetal origin, in the treatment of diseases caused by protozoa [83].

The essential oils of E. uniflora and S. cumini showed anti-Leishmanial activity. Eugenia uniflora oil from Brazil, rich in curzerene $(47.3 \%)$, displayed significant anti-Leishmanial activity against promastigote $\left(\mathrm{IC}_{50}, 3.04 \mu \mathrm{g} / \mathrm{mL}\right.$ ) and amastigote ( $\mathrm{IC}_{50} 1.92 \mu \mathrm{g} / \mathrm{mL}$ ) forms of Leishmania amazonensis. The oil was 20 times more toxic to amastigotes than to healthy macrophages. Although the anti-Leishmanial activity was not mediated by nitric oxide production, the authors have suggested that macrophage activation may be involved in the anti-Leishmanial activity of Eugenia uniflora essential oil, as evidenced by increases in both the phagocytic capacity and lysosomal activity [47]. Moreover, the essential oil of Syzygium cumini collected in Maranhão state (Brazil), rich in $\alpha$-pinene (31.85\%), showed anti-Leishmanial activity against promastigote form of L. amazonensis ( $\mathrm{IC}_{50} 60 \mu \mathrm{g} / \mathrm{mL}$ ) [67].

\subsection{Antioxidant Aactivity}

The antioxidants usually act as free radical scavengers, preventing oxidative stress, decreasing the possibility of chronic and degenerative diseases, controlling the autoxidation, and interrupting the propagation of free radicals, or by inhibiting the formation of free radicals via different mechanisms. Some aromatic plants are sources of natural antioxidants [83-86]. The antioxidant activity of Eugenia essential oils has been evaluated by radical scavenging DPPH, ABTS, and TLC methods, lipid peroxidation by $\beta$-carotene/linoleic acid, and the iron ion reduction power.

The oil of E. involucrata, obtained by supercritical fluid extraction (SFE), showed inhibition of 93.6\% to the $\beta$-carotene oxidation, while its oil extracted by hydrodistillation was shown to be inactive, with only $6.4 \%$ of inhibition. The main compounds were $\beta$-elemene $(41.8-42.4 \%)$, bicyclogermacrene (23.0-28.4\%), and (E)-caryophyllene (6.7-13.4\%), in both oil samples. The higher activity of the sample obtained by the extraction using SFE can be attributed to the nonvolatile compounds present in the extract [38,87]. Additionally, its fruit oil was rich in $(E)$-caryophyllene (10.1\%), spathulenol (7.8\%), and $\beta$-bisabolene (7.2\%), displaying a significant antioxidant activity by TLC-DPPH method [40].

The oils of E. uniflora collected in the Brazilian Amazon with different chemical profiles showed more antioxidant activity in the DPPH method than using the $\beta$-carotene/linoleic acid system [48]. Two different samples with higher content of caryophyllene oxide, selin-1,3,7(11)-trien-8-one, selin-1,3,7(11)-trien-8-one epoxide, and curzerene (50.6\%) presented an inhibition of DPPH radical of $45.1 \%(228.3 \mathrm{mgTE} / \mathrm{g})$ and $42.8 \%(217.0 \mathrm{mgTE} / \mathrm{g})$, respectively [47]. The leaf oils rich in curzerene (36.2-53.1\%) exhibited an antioxidant capacity varying from moderate (42.6\%) to high (64.2\%), according to seasonality and corresponding to $186.9 \mathrm{mgTE} / \mathrm{g}$ and $400.3 \mathrm{mgTE} / \mathrm{g}$, respectively [76]. The leaf oils rich in germacrene $\mathrm{B}(18.4 \%)$, curzerene $(13.4 \%)$ and (E)-caryophyllene $(9.1 \%)$ exhibited an inhibition of $40.6 \%$ (205.6 mgTE/g), and the oil samples rich in selin-1,3,7(11)-trien-8-one (32.6-43.1\%) and selin-1,3,7(11)-trien-8-one epoxide (21.7-30.4\%), displayed a DPPH radical scavenging of 30.3-35.3\%, corresponding to 153.5-178.8 mgTE/g [48]. Another specimen of E. uniflora, collected in South Brazil, with an oil rich in germacrene B (21.2\%) and selin-1,3,7-(11)-trien-8-one epoxide (19.3\%), displayed low activity in the DPPH method $\left(\mathrm{IC}_{50} 833 \mu \mathrm{g} / \mathrm{mL}\right)$ and high activity to reduce ABTS radical ( $\mathrm{IC}_{50}$ $8.1 \mu \mathrm{g} / \mathrm{mL}$ ). The results have suggested that its antioxidant activity mechanism is based on electron transfer [57]. Additionally, the EO from fruits, composed of hexadecanoic acid (11.7\%), (E)- $\beta$-ocimene (7.4\%), and $\alpha$-selinene (7.2\%) showed a high antioxidant potential by TLC-DPPH method [40].

The essential oil of E. egensis, rich in 5-hydroxy-cis-calemenene (35.8\%), displayed a strong DPPH radical scavenging $(79.6 \%, 216.5 \mathrm{mgTE} / \mathrm{mL}, 177.6 \mathrm{mg}$. BHAE $/ \mathrm{mL})$, about five times less than the standards Trolox and BHA [37]. On the other hand, the E. flavescens oil, rich in (E)- $\gamma$-bisabolene (35.0\%) and $\beta$-bisabolene $(34.7 \%)$, showed a moderate DPPH radical scavenging $(45.1 \%, 122.6 \mathrm{mgTE} / \mathrm{mL}$, 
$100.6 \mathrm{mgBHAE} / \mathrm{mL})$. Additionally, the E. patrisii oil, rich in $(2 E, 6 E)$-farnesol $(34.5 \%)$ and $(2 E, 6 Z)$-farnesol (23.2\%), presented a moderate inhibition of $40.9 \%(111.2 \mathrm{mgTE} / \mathrm{mL}, 91.3 \mathrm{mgBHAE} / \mathrm{mL})$ [37]. The oil of E. brasiliensis displayed a low activity against DPPH ( $\left.\mathrm{IC}_{50}>500 \mu \mathrm{g} / \mathrm{mL}\right), \beta$-carotene/linoleic acid (1.67-14.05\%), and iron reducing power (60.37-94.32 mg.AA/g) methods [71]. Similarly, the oil of E. polystachya showed a low activity (11.5\%) against the DPPH method [37].

\subsection{Other Biological Activities}

The oils of E. langsdorff from Brazil showed promise as a natural acaricide, with high fumigation potential observed for the leaf oil rich in epi-longipinanol (13.6\%), $\gamma$-eudesmol (12.3\%), limonene $(11.8 \%)$, and $10-$ epi- $\gamma$-eudesmol $(10.6 \%)$, and the fruit oil, where predominated 10-epi- $\gamma$-eudesmol $(35.7 \%)$ and 1,10-di-epi-cubenol (15.6\%). The LC $_{50}$ (median lethal concentration) values determined for the leaf and fruit oils were $1.7 \mu \mathrm{L} / \mathrm{L}$ and $3.06 \mu \mathrm{L} / \mathrm{L}$ in air. However, in the experiment based on the residual contact, the effect of the leaf oil $\left(\mathrm{LC}_{50} 21.90 \mu \mathrm{L} / \mathrm{L}\right)$ was less toxic than the fruit oil ( $\mathrm{LC}_{50}$ $12.25 \mu \mathrm{L} / \mathrm{L})[42]$.

The oils of E. stictopetala ( $\left.\mathrm{LC}_{50} 230 \mu \mathrm{g} / \mathrm{mL}\right)$ [63] and E. triquetra $(64.9 \mu \mathrm{g} / \mathrm{mL})$ were active as larvicidal against Aedes aegypti larvae [65]. The pure essential oil of E. sulcata applied as a topical treatment on the arthropods Oncopeltus fasciatus and Dysdercus peruvianus, caused a mortality rate of $96.7 \%$ and $80.0 \%$, respectively [45].

The essential oils of E. uniflora presented antinociceptive activity (ED $50218.6 \mathrm{mg} / \mathrm{kg}$ ), and hypothermic [52] and hepatoprotective effects induced by acetaminophen [88] in vivo assays with mice. Moreover, the Syzygium cumini oil from Rio de Janeiro state, Brazil, rich in $\alpha$-pinene $(22.2 \%),(Z)-\beta$-ocimene $(10.2 \%),(E)$-caryophyllene $(9.45 \%)$ showed anti-inflammatory activity by lipopolysaccharide-induced pleurisy model, with eosinophils inhibition of 67\% [66]. Additionally, S. cumini oil from São Luís state, Brazil, rich in $\alpha$-pinene (31.85\%), (Z)- $\beta$-ocimene (28.98\%), and $(E)$ - $\beta$-ocimene (11.71\%), presented molluscicide potential against Biomphalaria glabrata (LC $\mathrm{L}_{50}$ $90 \mu \mathrm{g} / \mathrm{mL}$ ) [67]. The distribution of reports on the biological activity of Eugenia and Syzygium species with occurrence in South America are represented in Figure 2.

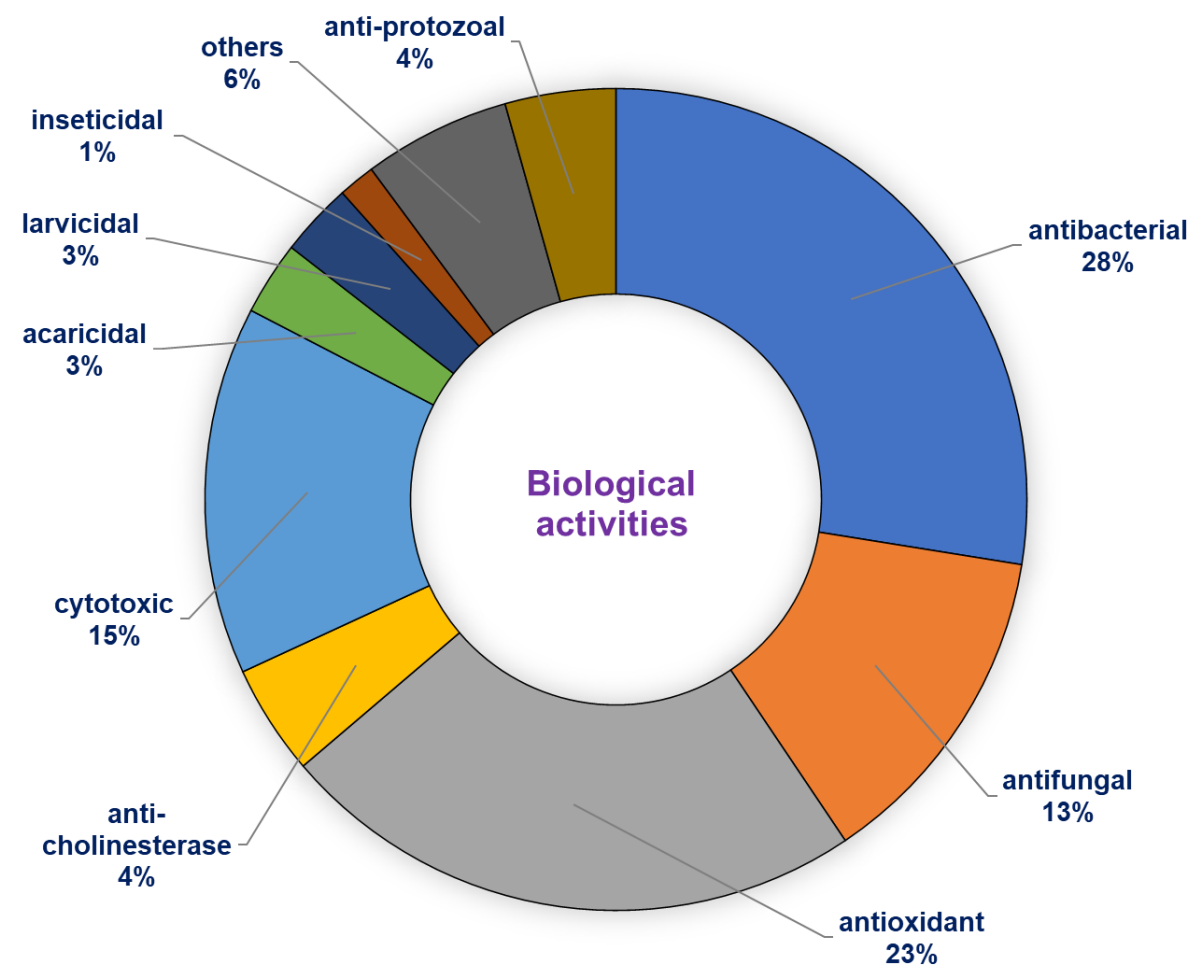

Figure 2. Distribution of reports on biological activity of Eugenia and Syzygium species. 


\section{Conclusions}

The Eugenia and Syzygium species from South America have high chemical variability and several biological activities in their essential oils. Based on the present study, these variations can be attributed to different geographic occurrences or seasonal changes. Despite the medicinal use of Eugenia species in traditional therapy, few reports have been made about the biological activity of its essential oils (less than $5 \%$ of species in Brazil). On the other hand, the composition of oils from a large number of species (127 samples) is already known, representing $12.2 \%$ of the total species distributed in Brazil. The variations in the chemical profile of these species indicated the importance of optimizing the protocols for collecting, processing, and extracting plant material. The standardization of these essential oils can contribute to the economic and commercial exploitation of bioactive products from aromatic plants.

Author Contributions: J.S.d.C. and E.d.N.S.d.C.: conceptualization, investigation, resources, writing-original draft, writing-review and editing. W.N.S., J.K.d.R.d.S. and J.G.S.M.: writing-review, supervision and editing. P.L.B.F.: conceptualization, investigation, resources, writing-review and editing, and supervision. All authors have read and agreed to the published version of the manuscript.

Funding: The authors are grateful to the Fundação Amazônia de Amparo a Estudos e Pesquisas (FAPESPA-Amazon Foundation for Support to Studies and Research) for providing a scholarship to E.N.S. Cruz and PROPESP (Universidade Federal do Pará/Brazil).

Acknowledgments: The authors are grateful to CNPq and Capes, institutions for scientific support and scholarship of the Brazilian Government.

Conflicts of Interest: The authors declare no conflict of interest.

\section{Abbreviations}

$\begin{array}{ll}\text { ABTS } & \text { 2:2'-azino-bis (3-ethylbenzothiazoline-6-sulfonic acid) } \\ \text { ACh } & \text { Acetylcholine } \\ \text { AChE } & \text { Acetylcholine esterase } \\ \text { BHA } & \text { Butylated hydroxyanisole } \\ \text { BR } & \text { Brazil } \\ \text { CO } & \text { Colombia } \\ \text { DPPH } & \text { 2,2-Diphenyl-1-picrylhydrazyl (radical) } \\ \text { ED50 } & \text { Median Effective dose } \\ \text { EOs } & \text { Essential oils } \\ \text { GC-MS } & \text { Gas chromatography-mass spectrometry } \\ \text { HCA } & \text { Hierarchical Cluster Analysis } \\ \text { HD } & \text { Hydrodistillation } \\ \text { IC50 } & \text { Median inhibitory concentration } \\ \text { LC50 } & \text { Median lethal concentration } \\ \text { mg.AA/g } & \text { Milligram of ascorbic acid per gram } \\ \text { mg.BHAE/mL } & \text { Milligram BHA equivalente per gram } \\ \text { mgTE/g } & \text { Milligram trolox equivalente per gram } \\ \text { MIC } & \text { Minimum inhibitory concentration } \\ \text { MMC } & \text { Minimum microbicide concentration } \\ \text { NI } & \text { Unidentified compound } \\ \text { NMR } & \text { Nuclear magnetic resonance } \\ \text { PCA } & \text { Principal cluster analysis } \\ \text { SD } & \text { Steam distillation } \\ \text { SFE } & \text { Supercritical fluid extraction } \\ \text { SPME } & \text { Solid Phase Micro Extraction } \\ \text { spp. } & \text { Species (plural) } \\ \text { TLC } & \text { Thin-layer chromatography } \\ \text { VE } & \text { Venezuela } \\ & \end{array}$




\section{Appendix A}

Table A1. Species of Eugenia and Syzygium in South America: essential oil composition and biological activity.

\begin{tabular}{|c|c|c|c|c|c|}
\hline Species & Occurrence & Essential Oil & Primary Components $(>5 \%)$ & Essential Oil Bioactivity & Ref. \\
\hline E. acutata & $\begin{array}{l}\text { Valinhos, São Paulo, } \\
\text { Brazil }\end{array}$ & Leaf (SD) & $\begin{array}{l}\text { E-caryophyllene }(26.93 \%), \delta \text {-cadinene } \\
(6.01 \%), \text { germacrene D }(5.29 \%)\end{array}$ & - & [60] \\
\hline E. arenosa & $\begin{array}{l}\text { Manuel Viana, Rio } \\
\text { Grande do Sul, Brazil }\end{array}$ & Leaf (HD) & $\begin{array}{l}\text { farnesyl acetate }(70.4 \%) \text {, aromadendrene } \\
(11.7 \%) \text {, globulol }(7.1 \%)\end{array}$ & - & [32] \\
\hline E. astringens & $\begin{array}{l}\text { Macaé, Rio de Janeiro, } \\
\text { Brazil }\end{array}$ & Leaf (HD) & $\begin{array}{c}\alpha \text {-pinene }(15.8 \%), 1 \text {-epi-cubenol }(11.9 \%) \\
\alpha \text {-eudesmol }(10.6 \%) \text {, selin-11-en- } 4 \alpha \text {-ol } \\
(9.4 \%)\end{array}$ & - & [28] \\
\hline E. astringens & $\begin{array}{l}\text { Rio de Janeiro, Rio de } \\
\text { Janeiro, Brazil }\end{array}$ & Leaf (HD) ${ }^{b}$ & $\begin{array}{c}\alpha \text {-pinene }(19.7-34.4 \%), \beta \text {-pinene } \\
(20.6-34.1 \%), E \text {-caryophyllene }(3.6-11.7 \%)\end{array}$ & - & [26] \\
\hline E. astringens & $\begin{array}{c}\text { Juréia, São Paulo, } \\
\text { Brazil }\end{array}$ & Leaf (HD) & $\begin{array}{c}\alpha \text {-pinene }(24.7 \%), E \text {-caryophyllene } \\
(14.6 \%), \beta \text {-pinene }(11.0 \%), \text { myrcene } \\
(7.7 \%)\end{array}$ & - & [27] \\
\hline E. astringens & $\begin{array}{l}\text { Santo Amaro } \\
\text { da Imperatriz, Santa } \\
\text { Catarina, Brazil }\end{array}$ & Leaf (HD) & $\begin{array}{c}\text { viridiflorol }(17.7 \%), \beta \text {-pinene }(13.2 \%), \\
\alpha \text {-pinene }(11.2 \%), \text { aromadendrene }(6.9 \%)\end{array}$ & $\begin{array}{c}\text { Antibacterial, broth dilution assay (Staphylococcus aureus, } \\
\text { MIC } 119.2 \mu \mathrm{g} / \mathrm{mL} ; \text { Pseudomonas aeruginosa, } \\
\text { MIC } 447.0 \mu \mathrm{g} / \mathrm{mL} ; \\
\text { Escherichia coli, MIC } 477.0 \mu \mathrm{g} / \mathrm{mL} \text { ) }\end{array}$ & [29] \\
\hline E. bacopari & $\begin{array}{l}\text { Dom Pedro de } \\
\text { Alcantara, Rio Grande } \\
\text { do Sul, Brazil }\end{array}$ & Leaf (HD) & $\begin{array}{c}\delta \text {-cadinene }(15.8 \%), \text { aromadendrene } \\
(12.2 \%) \text {, viridiflorene }(7.9 \%), \text { globulol } \\
(6.8 \%)\end{array}$ & - & [59] \\
\hline E. beaurepaireana & $\begin{array}{l}\text { Morrinhos do Sul, Rio } \\
\text { Grande do Sul, Brazil }\end{array}$ & Leaf (HD) & $\begin{array}{c}\text { bicyclogermacrene }(14.3 \%) \text {, germacrene } \\
\mathrm{D}(8.6 \%), \delta \text {-cadinene }(7.2 \%) \\
\text { E-caryophyllene }(6.4 \%)\end{array}$ & - & {$[30]$} \\
\hline E. beaurepaireana & $\begin{array}{l}\text { Santo Amaro } \\
\text { da Imperatriz, Santa } \\
\text { Catarina, Brazil }\end{array}$ & Leaf (HD) & $\begin{array}{c}\text { E-caryophyllene }(8.0 \%) \\
\text { bicyclogermacrene }(7.2 \%), \text { valencene } \\
(5.5 \%), \delta \text {-cadinene }(4.9 \%), \text { spathulenol } \\
(4.9 \%) \text {, viridiflorol }(4.9 \%)\end{array}$ & $\begin{array}{l}\text { Antibacterial, broth dilution assay (Staphylococcus aureus, } \\
1110 \mu \mathrm{g} / \mathrm{mL} \text {; Pseudomonas aeruginosa, MIC } 278.3 \mu \mathrm{g} / \mathrm{mL} ; \\
\text { Escherichia coli, MIC } 556.6 \mu \mathrm{g} / \mathrm{mL} \text { ) }\end{array}$ & [29] \\
\hline E. biflora & Belém, Pará, Brazil & Leaf (HD) & $\begin{array}{c}\text { caryophyllene oxide }(28.6 \%) \\
\text { E-caryophyllene }(16.8 \%), \tau \text {--murrolol } \\
(8.4 \%), 1 \text {-epi-cubenol }(6.4 \%), \alpha \text {-cadinol } \\
(6.2 \%)\end{array}$ & - & [24] \\
\hline
\end{tabular}


Table A1. Cont.

\begin{tabular}{|c|c|c|c|c|c|}
\hline Species & Occurrence & Essential Oil & Primary Components $(>5 \%)$ & Essential Oil Bioactivity & Ref. \\
\hline E. biflora & Belém, Pará, Brazil & Leaf (HD) & $\begin{array}{c}\text { caryophyllene oxide }(20.5 \%) \\
\text { E-caryophyllene }(11.4 \%), \text { epi- } \alpha \text {-murrolol } \\
(7.6 \%), 1 \text {-epi-cubenol }(6.6 \%), \alpha \text {-cadinol } \\
(6.3 \%)\end{array}$ & - & [24] \\
\hline E. biflora & Belém, Pará, Brazil & Leaf (HD) & $\begin{array}{l}\text { E-caryophyllene }(9.8 \%) \text {, globulol }(9,8 \%), \\
\text { germacrene B }(7.9 \%), \alpha \text {-cadinol }(7.5 \%)\end{array}$ & - & [24] \\
\hline E. biflora & Belém, Pará, Brazil & Leaf (HD) & $\begin{array}{c}\alpha \text {-cadinol }(14.7 \%), \tau \text {-murrolol }(8.3 \%) \\
\text { caryophyllene oxide }(7.5 \%) \text {, copaborneol } \\
(5.6 \%)\end{array}$ & - & [24] \\
\hline E. biflora & Maracanã, Pará, Brazil & Leaf (HD) & $\begin{array}{c}\text { E-caryophyllene }(15.4 \%) \text {, germacrene D } \\
(6.6 \%), \alpha \text {-copaene }(6.0 \%), \\
\text { bicyclogermacrene }(5.8 \%)\end{array}$ & - & [25] \\
\hline E. biflora & Maracanã, Pará, Brazil & Leaf (HD) & $\begin{array}{c}\beta \text {-pinene }(27.8 \%), \alpha \text {-pinene }(27.3 \%), \\
\text { limonene }(6.7 \%)\end{array}$ & - & [25] \\
\hline E. brasiliensis & $\begin{array}{l}\text { Blumenau, Santa } \\
\text { Catarina, Brazil }\end{array}$ & Leaf (HD) & $\begin{array}{l}\beta \text {-pinene }(10.4 \%), \alpha \text {-pinene }(10.3 \%), \\
\text { spathulenol }(7.7 \%), \tau \text {-cadinol }(7.1 \%)\end{array}$ & - & [32] \\
\hline E. brasiliensis & $\begin{array}{l}\text { Florianópolis, Santa } \\
\text { Catarina, Brazil }\end{array}$ & Leaf $(\mathrm{HD})^{\mathrm{b}}$ & $\begin{array}{c}\alpha \text {-pinene }(1.77-15.94 \%), \beta \text {-pinene } \\
(2.98-11.24 \%), \\
\text { spathulenol }(8.10-18.17 \%), 1-\text { epi-cubenol } \\
(4.83-7.46 \%), \tau \text {-cadinol }(10.38-15.30 \%)\end{array}$ & $\begin{array}{c}\text { Antibacterial, broth dilution assay } \\
(\text { Staphylococcus saprophyticus, } \\
\text { MIC 500-1000 } \mu \mathrm{g} / \mathrm{mL} ; \text { Escherichia coli, MIC } 1000 \mu \mathrm{g} / \mathrm{mL} ; \\
\text { Pseudomonas aeruginosa, MIC } 500-1000 \mu \mathrm{g} / \mathrm{mL}) \\
\text { Antioxidant (DPPH } \mathrm{IC}_{50}>500 \mu \mathrm{g} / \mathrm{mL} ; \beta \text {-carotene/linoleic } \\
\text { acid, } 1.67-14.05 \% \text {; iron reducing power, } \\
60.37-94.32 \mathrm{mg} \text { AA } / \mathrm{g}) \\
\text { Enzyme inhibitory }(\text { acetylcholinesterase, } \\
\left.\mathrm{IC}_{50}>1000 \mu \mathrm{g} / \mathrm{mL}\right)\end{array}$ & [71] \\
\hline E. brasiliensis & $\begin{array}{l}\text { Moji-Guaçu, São } \\
\text { Paulo, Brazil }\end{array}$ & $\begin{array}{l}\text { Leaf Purple } \\
\text { Variety (HD) }\end{array}$ & $\begin{array}{c}\alpha \text {-pinene }(18.8 \%), \beta \text {-pinene }(11.0 \%), \\
\text { 1,8-cineol }(9.6 \%), \text { limonene }(8.6 \%), \\
\tau \text {-cadinol }(6.8 \%)\end{array}$ & - & [33] \\
\hline E. brasiliensis & $\begin{array}{l}\text { Moji-Guaçu, São } \\
\text { Paulo, Brazil }\end{array}$ & $\begin{array}{l}\text { Leaf Yellow } \\
\text { Variety (HD) }\end{array}$ & $\begin{array}{c}\alpha \text {-pinene }(33.5 \%), 1,8 \text {-cineol }(28.2 \%), \\
\beta \text {-pinene }(14.4 \%), \text { myrcene }(5.5 \%)\end{array}$ & - & [33] \\
\hline
\end{tabular}


Table A1. Cont.

\begin{tabular}{|c|c|c|c|c|c|}
\hline Species & Occurrence & Essential Oil & Primary Components $(>5 \%)$ & Essential Oil Bioactivity & Ref. \\
\hline E. brasiliensis & $\begin{array}{l}\text { Moji-Guaçu, São } \\
\text { Paulo, Brazil }\end{array}$ & $\begin{array}{l}\text { Fruit Yellow } \\
\text { Variety (HD) }\end{array}$ & $\begin{array}{c}\alpha \text {-pinene }(15.4 \%), \text { myrcene }(10.7 \%) \\
\alpha \text {-terpineol }(10.2 \%), \beta \text {-pinene }(9.3 \%)\end{array}$ & - & [33] \\
\hline E. brasiliensis & $\begin{array}{l}\text { Santo Amaro } \\
\text { da Imperatriz, Santa } \\
\text { Catarina, Brazil }\end{array}$ & Leaf (HD) & $\begin{array}{l}\text { spathulenol }(12.7 \%), \tau \text {-cadinol }(8.7 \%) \text {, } \\
\text { viridiflorol }(7.1 \%), 1 \text {-epi-cubenol }(6.3 \%) \text {, } \\
\text { } \alpha \text {-cadinol }(6.6 \%)\end{array}$ & $\begin{array}{c}\text { Antibacterial, broth dilution assay (Staphylococcus aureus, } \\
\text { MIC } 156.2 \mu \mathrm{g} / \mathrm{mL} \text {; Pseudomonas aeruginosa, } \\
\text { MIC } 624.9 \mu \mathrm{g} / \mathrm{mL} ; \\
\text { Escherichia coli, MIC } 624.9 \mu \mathrm{g} / \mathrm{mL} \text { ) }\end{array}$ & [29] \\
\hline E. brasiliensis & $\begin{array}{c}\text { São Paulo, São Paulo, } \\
\text { Brazil }\end{array}$ & Leaf (HD) ${ }^{b}$ & $\begin{array}{c}\text { spathulenol }(7.0-18.0 \%) \\
\text { trans- } \alpha \text {-bergamotene }(2.6-19.0 \%), \\
\alpha \text {-thujene }(4.0-11.5 \%), \beta-\text {-selinene } \\
(2.3-8.5 \%)\end{array}$ & - & [72] \\
\hline E. brasiliensis & $\begin{array}{l}\text { Moji-Guaçu, São } \\
\text { Paulo, Brazil }\end{array}$ & $\begin{array}{l}\text { Fruit Purple } \\
\text { Variety } \\
\text { (HD) }\end{array}$ & $\begin{array}{c}\text { caryophyllene oxide }(22.2 \%), \alpha \text {-cadinol } \\
(10.4 \%), \\
\tau \text {-cadinol }(9.9 \%), \beta \text {-bisabolene }(9.6 \%)\end{array}$ & - & [33] \\
\hline E. burkartiana & $\begin{array}{l}\text { Parque do Turvo, Rio } \\
\text { Grande do Sul, Brazil }\end{array}$ & Leaf (HD) & $\begin{array}{c}\text { bicyclogermacrene }(14.2 \%) \text {, germacrene } \\
\mathrm{D}(8.8 \%), E \text {-caryophyllene }(7.8 \%) \\
3 E \text {-hexenol }(6.7 \%)\end{array}$ & - & [59] \\
\hline E. candolleana & $\begin{array}{c}\text { Rio de Janeiro, } \\
\text { Rio de Janeiro, Brazil }\end{array}$ & Leaf (SD) & $\begin{array}{c}\text { 1-epi-cubenol (77.59\%), } \delta \text {-elemene } \\
(13.87 \%), \text { muurola-4,10(14)-dien-1 } \beta \text {-ol } \\
(8.68 \%) \text {, globulol (5.52\%), } \\
\alpha \text {-cadinol }(5.26 \%)\end{array}$ & - & [60] \\
\hline E. catharinensis & $\begin{array}{c}\text { Blumenau, Santa } \\
\text { Catarina, Brazil }\end{array}$ & Leaf (HD) & $\begin{array}{c}\text { ethyl palmitate }(10.5 \%) \text {, } \\
\text { trans- } \alpha \text {-bergamotene }(6.5 \%), \beta \text {-selinene } \\
(5.9 \%)\end{array}$ & - & [59] \\
\hline E. chlorophylla & $\begin{array}{c}\text { Curitiba, Paraná, } \\
\text { Brazil }\end{array}$ & $\begin{array}{l}\text { Fine Stem } \\
\quad(\mathrm{HD})\end{array}$ & $\begin{array}{c}\text { caryophyllene oxide }(17.2 \%), \tau \text {-muurolol } \\
(16.8 \%) \text {, globulol }(16.5 \%), \alpha \text {-cadinol } \\
(12.1 \%), \\
\text { 1-epi-cubenol }(10.9 \%)\end{array}$ & $\begin{array}{c}\text { Antimicrobial, agar diffusion assay and broth dilution } \\
\text { assay (Kocuria rhizophila, MIC } 500 \mu \mathrm{g} / \mathrm{mL} ; \\
\text { Staphylococcus aureus, MIC } 500 \mu \mathrm{g} / \mathrm{mL} ; \\
\text { Streptococcus mutans, MIC } 50.0 \mu \mathrm{g} / \mathrm{mL} ; \\
\text { Streptococcus sobrinus, } \\
\text { MIC } 50.0 \mu \mathrm{g} / \mathrm{mL} \text {; Candida tropicalis, MIC } 50.0 \mu \mathrm{g} / \mathrm{mL} \text { ) }\end{array}$ & [34] \\
\hline
\end{tabular}


Table A1. Cont.

\begin{tabular}{|c|c|c|c|c|c|}
\hline Species & Occurrence & Essential Oil & Primary Components $(>5 \%)$ & Essential Oil Bioactivity & Ref. \\
\hline E. chlorophylla & $\begin{array}{l}\text { Curitiba, Paraná, } \\
\text { Brazil. }\end{array}$ & Leaf (HD) & $\begin{array}{c}\text { globulol }(22.5 \%), 1-10-\text { di-epi-cubenol, } \\
(9.8 \%), \tau \text {-muurolol }(8.1 \%), \text { caryophyllene } \\
\text { oxide }(6.4 \%)\end{array}$ & $\begin{array}{l}\text { Antimicrobial, agar diffusion assay and broth dilution } \\
\text { assay (Kocuria rhizophila, MIC 500,50.0 } \mu \mathrm{g} / \mathrm{mL} ; \\
\text { Staphylococcus aureus, MIC 500, } 50.0 \mu \mathrm{g} / \mathrm{mL} ; \\
\text { Streptococcus mutans, MIC } 50.0 \mu \mathrm{g} / \mathrm{mL} ; \\
\text { Streptococcus sobrinus, MIC } 50.0 \mu \mathrm{g} / \mathrm{mL} \text {; Candida albicans, } \\
\text { MIC } 50.0 \mu \mathrm{g} / \mathrm{mL} ; \\
\text { Candida tropicalis, MIC } 50.0 \mu \mathrm{g} / \mathrm{mL} \text { ) }\end{array}$ & [34] \\
\hline E. chlorophylla & $\begin{array}{c}\text { Curitiba, Paraná, } \\
\text { Brazil }\end{array}$ & $\begin{array}{c}\text { Leaf at } \\
\text { flowering } \\
\text { stage }(\mathrm{HD})\end{array}$ & $\begin{array}{l}\text { globulol }(18.9 \%), \alpha \text {-cadinol }(9.4 \%), \\
\text { 1-epi-cubenol }(8.1 \%), \text {-caryophyllene } \\
(8.1 \%) \text {, caryophyllene oxide }(5.8 \%)\end{array}$ & $\begin{array}{c}\text { Antimicrobial, agar diffusion assay and broth dilution } \\
\text { assay (Kocuria rhizophila, MIC } 500 \mu \mathrm{g} / \mathrm{mL} \text {; Staphylococcus } \\
\text { aureus, MIC } 500 \mu \mathrm{g} / \mathrm{mL} \text {; Streptococcus mutans, } \\
\text { MIC } 50.0 \mu \mathrm{g} / \mathrm{mL} \text {; Streptococcus sobrinus, } \\
\text { MIC } 50.0 \mu \mathrm{g} / \mathrm{mL} \text {; Candida albicans, MIC } 50.0 \mu \mathrm{g} / \mathrm{mL} \text {; } \\
\text { Candida tropicalis, } 50.0 \mu \mathrm{g} / \mathrm{mL} \text { ) }\end{array}$ & [34] \\
\hline E. chlorophylla & $\begin{array}{c}\text { Curitiba, Paraná, } \\
\text { Brazil }\end{array}$ & Flower (HD) & $\begin{array}{c}\text { E-caryophyllene }(12.8 \%), \alpha \text {-cadinol } \\
(10.1 \%) \text {, caryophyllene oxide }(8.9 \%), \\
\tau \text {-muurolol }(8.5 \%)\end{array}$ & $\begin{array}{l}\text { Antimicrobial, agar diffusion assay and broth dilution } \\
\text { assay (Kocuria rhizophila, MIC } 500 \mu \mathrm{g} / \mathrm{mL} \text {; Staphylococcus } \\
\text { aureus, MIC } 500 \mu \mathrm{g} / \mathrm{mL} \text {; Streptococcus mutans, } \\
\text { MIC } 50.0 \mu \mathrm{g} / \mathrm{mL} \text {; Streptococcus sobrinus, MIC } 50.0 \mu \mathrm{g} / \mathrm{mL} \text {; } \\
\text { Enterococcus faecalis, MIC } 1000 \mu \mathrm{g} / \mathrm{mL} \text { ) }\end{array}$ & [34] \\
\hline E. copacabanensis & $\begin{array}{l}\text { Rio de Janeiro, Rio de } \\
\text { Janeiro, Brazil }\end{array}$ & Leaf (SD) & $\begin{array}{c}\text { 1,10-di-epi-cubenol }(14.24 \%) \\
\text { caryophyllene oxide }(6.75 \%), \\
\text { epi- } \alpha \text {-cadinol }(5.03 \%), \gamma \text {-cadinene }(4.17 \%)\end{array}$ & - & [60] \\
\hline E. copacabanensis & $\begin{array}{l}\text { Rio de Janeiro, Rio de } \\
\text { Janeiro, Brazil }\end{array}$ & Leaf (HD) & $\begin{array}{c}\beta \text {-pinene }(50.4 \%), \alpha \text {-pinene }(20.2 \%), \\
E \text {-caryophyllene }(10.3 \%)\end{array}$ & - & [89] \\
\hline E. dimorpha & $\begin{array}{l}\text { Morro Santana, Rio } \\
\text { Grande do Sul, Brazil }\end{array}$ & Leaf (HD) & $\begin{array}{c}\alpha \text {-pinene }(22.4 \%), \alpha \text {-humulene }(12.9 \%), \\
1,8 \text {-cineole }(9.9 \%)\end{array}$ & - & [59] \\
\hline E. dysenterica & Catalão, Goiás, Brazil & Leaf (HD) & $\begin{array}{c}\text { E-caryophyllene }(14.8 \%), \alpha \text {-humulene } \\
(11.0 \%), \alpha \text {-terpineol }(6.1 \%), \text { limonene } \\
(5.5 \%), \delta \text {-cadinene }(5.8 \%), \text { caryophyllene } \\
\text { oxide }(5.4 \%)\end{array}$ & $\begin{array}{l}\text { Antibacterial, broth dilution assay } \\
\text { (Cryptococcus neoformans var neoformans, MIC } 250 \mu \mathrm{g} / \mathrm{mL} \text {; } \\
\text { Cryptococcus neoformans var gattii, } \\
\text { MIC } 250 \mu \mathrm{g} / \mathrm{mL} \text { ) }\end{array}$ & [35] \\
\hline E. dysenterica & $\begin{array}{l}\text { Senador Canedo Santa } \\
\text { Catarina, Brazil }\end{array}$ & Leaf (HD) & $\begin{array}{c}\text { E-caryophyllene }(18.0 \%), \beta \text {-pinene } \\
(9.3 \%), \alpha \text {-pinene }(9.0 \%), \text { limonene }(7.8 \%), \\
\text { Z- } \beta \text {-ocimene }(5.9 \%)\end{array}$ & - & [36] \\
\hline
\end{tabular}


Table A1. Cont.

\begin{tabular}{|c|c|c|c|c|c|}
\hline Species & Occurrence & Essential Oil & Primary Components $(>5 \%)$ & Essential Oil Bioactivity & Ref. \\
\hline E. dysenterica & $\begin{array}{l}\text { Campo Alegre de } \\
\text { Goiás, Goiás, Brazil }\end{array}$ & Leaf (HD) & $\begin{array}{c}\text { E-caryophyllene }(24.0 \%), \delta \text {-cadinene } \\
(13.0 \%), \alpha \text {-copaene }(9.6 \%), \alpha \text {-pinene } \\
(6.4 \%), \\
\text { caryophyllene oxide }(4.5 \%)\end{array}$ & - & [36] \\
\hline E. egensis & Marabá, Pará, Brazil & $\begin{array}{l}\text { Aerial parts } \\
\text { (HD) }\end{array}$ & $\begin{array}{c}\text { 5-hydroxy-Z-calamenene }(35.8 \%), \\
\text { E-caryophyllene }(8.9 \%), \\
\text { trans-muurola-3,5-diene }(5.9 \%), \\
\text { trans-calamenene }(6.1 \%) \\
\text { trans-cadin-1,4-diene }(6.3 \%) \\
\text { ledol }(5.0 \%)\end{array}$ & $\begin{array}{c}\text { Antioxidant, DPPH assay }(79.6 \%, 216.5 \mathrm{mgTE} / \mathrm{mL}, \\
177.6 \mathrm{mgBHAE} / \mathrm{mL}) \\
\text { Cytotoxic }(\mathrm{HCT}-116 \text { human colorectal carcinoma, } \\
\mathrm{IC}_{50}>25 \mu \mathrm{g} / \mathrm{mL} ; \text { MRC5 human fibroblast } \\
\mathrm{IC}_{50}>25 \mu \mathrm{g} / \mathrm{mL} ; \mathrm{AGP}-01 \text { human gastric adenocarcinoma, } \\
\mathrm{IC}_{50}>25 \mu \mathrm{g} / \mathrm{mL} ; \text { SKMEL-19 human melanoma, } \\
\left.\text { IC }{ }_{50}>25 \mu \mathrm{g} / \mathrm{mL}\right)\end{array}$ & [37] \\
\hline E. expansa & $\begin{array}{l}\text { Peruíbe, São Paulo, } \\
\text { Brazil }\end{array}$ & Leaf (HD) & $\begin{array}{c}\text { spathulenol }(12.1 \%), E \text {-caryophyllene } \\
(9.2 \%) \text {, caryophyllene oxide }(8.7 \%) \\
\alpha \text {-copaene }(5.0 \%)\end{array}$ & - & [32] \\
\hline E. flavescens & Maracanã, Pará, Brazil & Leaf (HD) & $\begin{array}{c}\text { germacrene } \mathrm{D}(14.5 \%), \\
\text { bicyclogermacrene }(11.7 \%), \\
\delta \text {-cadinene }(5.7 \%)\end{array}$ & - & [25] \\
\hline E. flavescens & $\begin{array}{c}\text { Parauapebas, Pará, } \\
\text { Brazil }\end{array}$ & $\begin{array}{l}\text { Aerial parts } \\
\quad(\mathrm{HD})\end{array}$ & $\begin{array}{c}E \text { - } \gamma \text {-bisabolene }(35.0 \%), \beta \text {-bisabolene } \\
(34.7 \%) \\
\text { E-iso- } \gamma \text {-bisabolene }(5.1 \%)\end{array}$ & $\begin{array}{c}\text { Antioxidant, DPPH assay }(45.1 \%, 122.6 \mathrm{mgTE} / \mathrm{mL} \text {, } \\
100.6 \mathrm{mgBHAE} / \mathrm{mL}) \\
\text { Cytotoxic }(\mathrm{HCT}-116 \text { human colorectal carcinoma, } \\
\mathrm{IC}_{50} 13.99 \mu \mathrm{g} / \mathrm{mL} ; \text { MRC5 human fibroblast } \\
\mathrm{IC}_{50} 14.0 \mu \mathrm{g} / \mathrm{mL} ; \mathrm{AGP}-01 \text { human gastric adenocarcinoma, } \\
\mathrm{IC}_{50}>25 \mu \mathrm{g} / \mathrm{mL} ; \text { SKMEL-19 human melanoma, } \\
\left.\mathrm{IC}_{50}>25 \mu \mathrm{g} / \mathrm{mL}\right)\end{array}$ & [37] \\
\hline E. florida & $\begin{array}{c}\text { Derrubadas, Rio } \\
\text { Grande do Sul, Brazil }\end{array}$ & Leaf (HD) & $\begin{array}{c}\text { E-caryophyllene }(14.5 \%), \beta \text {-elemene } \\
(11.8 \%), \\
\alpha \text {-copaene }(7.9 \%), \alpha \text {-cadinol }(5.8 \%)\end{array}$ & - & [61] \\
\hline E. gracillima & $\begin{array}{l}\text { Porto Rico, Paraná, } \\
\text { Brazil }\end{array}$ & Leaf (HD) & $\begin{array}{l}\text { globulol }(8.7 \%) \text {, viridiflorene }(6.9 \%) \text {, } \\
\text { epi-globulol }(6.8 \%) \text {, spathulenol }(5.9 \%)\end{array}$ & - & [61] \\
\hline E. hiemalis & $\begin{array}{l}\text { Morro Santana, Rio } \\
\text { Grande do Sul, Brazil }\end{array}$ & Leaf (HD) & $\begin{array}{c}\text { bicyclogermacrene }(37.7 \%), \\
\text { E-caryophyllene }(7.4 \%) \text {, germacrene D } \\
(7.0 \%) \text {, globulol }(5.8 \%)\end{array}$ & - & [62] \\
\hline
\end{tabular}


Table A1. Cont.

\begin{tabular}{|c|c|c|c|c|c|}
\hline Species & Occurrence & Essential Oil & Primary Components $(>5 \%)$ & Essential Oil Bioactivity & Ref. \\
\hline E. involucrata & $\begin{array}{l}\text { Urupema, Santa } \\
\text { Catarina, Brazil }\end{array}$ & Leaf (SFE) & $\begin{array}{c}\text { B-elemene }(41.8 \%), \text { bicyclogermacrene } \\
(28.4 \%), \\
\text { E-caryophyllene }(6.7 \%) \text {, germacrene D } \\
(7.4 \%)\end{array}$ & $\begin{array}{l}\text { Antioxidant ( } \beta \text {-carotene/ linoleic acid assay, at } 1 \mathrm{mg} / \mathrm{mL} \text {, } \\
93.8 \%)\end{array}$ & [38] \\
\hline E. involucrata & $\begin{array}{l}\text { Urupema, Santa } \\
\text { Catarina, Brazil }\end{array}$ & Leaf (HD) & $\begin{array}{c}\text { B-elemene }(42.4 \%), \text { bicyclogermacrene } \\
(23.0 \%), \\
\text { E-caryophyllene }(13.4 \%)\end{array}$ & $\begin{array}{l}\text { Antioxidant ( } \beta \text {-carotene/ linoleic acid assay, at } 1 \mathrm{mg} / \mathrm{mL} \text {, } \\
6.41 \%)\end{array}$ & [38] \\
\hline E. involucrata & $\begin{array}{l}\text { Uberlândia, Minas } \\
\text { Gerais, Brazil }\end{array}$ & Leaf (HD) & $\begin{array}{c}\text { spathulenol }(21.4 \%) \text {, bicyclogermacrene } \\
(19.3 \%), \text {-caryophyllene }(8.6 \%) \\
\text { caryophyllene oxide }(7.7 \%)\end{array}$ & $\begin{array}{c}\text { Antibacterial, broth dilution assay (Streptococcus mitis, } \\
\text { MIC } 400 \mu \mathrm{g} / \mathrm{mL} \text {; S. sanguinis, MIC } 400 \mu \mathrm{g} / \mathrm{mL} ; \text { Prevotella } \\
\text { nigrescens, MIC } 100 \mu \mathrm{g} / \mathrm{mL} ; \text { Porphyromonas gingivalis, MIC } \\
100 \mu \mathrm{g} / \mathrm{mL} \text { ) }\end{array}$ & [39] \\
\hline E. involucrata & $\begin{array}{l}\text { Pelotas, Rio Grande } \\
\text { do Sul, Brazil, }\end{array}$ & Fruit (HD) & $\begin{array}{c}\text { E-caryophyllene }(10.1 \%) \text {, spathulenol } \\
(7.8 \%), \\
\beta \text {-bisabolene }(7.2 \%), \gamma \text {-eudesmol }(6.0 \%)\end{array}$ & Antioxidant, DPPH assay (TLC method) & [40] \\
\hline E. joenssonii & $\begin{array}{l}\text { Morro Santana, Rio } \\
\text { Grande do Sul, Brazil }\end{array}$ & Leaf (HD) & $\begin{array}{c}\text { 5-epi-paradisiol }(8.4 \%), \delta \text {-selinene }(7.9 \%), \\
\beta \text {-selinene }(7.2 \%), \text { neointermedeol }(6.3 \%), \\
\alpha \text {-cadinol }(5.3 \%)\end{array}$ & - & [59] \\
\hline E. klotzschiana & $\begin{array}{l}\text { Portelândia, Goiás, } \\
\text { Brazil }\end{array}$ & Leaf (HD) & $\begin{array}{c}\alpha \text {-copaene }(10.6 \%), \alpha \text {-humulene }(5.5 \%) \\
\text { spathulenol }(8.7 \%), \text { caryophyllene oxide } \\
(7.4 \%), \tau \text {-muurolol }(5.4 \%) \alpha \text {-cadinol } \\
(6.2 \%)\end{array}$ & - & [41] \\
\hline E. klotzschiana & $\begin{array}{l}\text { Portelândia, Goiás, } \\
\text { Brazil }\end{array}$ & Leaf (HD) & $\begin{array}{c}\beta \text {-bisabolene }(14.0 \%) \text {, spathulenol } \\
(10.9 \%), \text { caryophyllene oxide }(6.3 \%) \\
\text { bicyclogermacrene }(5.4 \%)\end{array}$ & - & [41] \\
\hline E. klotzschiana & $\begin{array}{l}\text { Portelândia, Goiás, } \\
\text { Brazil }\end{array}$ & Leaf (HD) & $\begin{array}{c}\beta \text {-bisabolene }(17.4 \%), \text { germacrene D } \\
(13.3 \%), \\
\alpha \text {-humulene }(10.2 \%) \\
\alpha \text {-trans-bergamotene }(10.1 \%) \\
\text { spathulenol }(7.2 \%)\end{array}$ & - & [41] \\
\hline E. klotzschiana & $\begin{array}{l}\text { Portelândia, Goiás, } \\
\text { Brazil }\end{array}$ & Flower (HD) & $\begin{array}{c}\alpha \text {-trans-bergamotene }(29.9 \%) \\
\text { germacrene } D(12.1 \%), \beta \text {-bisabolene } \\
(10.2 \%)\end{array}$ & - & [41] \\
\hline
\end{tabular}


Table A1. Cont.

\begin{tabular}{|c|c|c|c|c|c|}
\hline Species & Occurrence & Essential Oil & Primary Components $(>5 \%)$ & Essential Oil Bioactivity & Ref. \\
\hline E. langsdorffi & $\begin{array}{l}\text { Brasília, Distrito } \\
\text { Federal, Brazil }\end{array}$ & Leaf (HD) & $\begin{array}{c}\text { epi-longipinanol }(13.6 \%), \gamma \text {-eudesmol } \\
(12.3 \%), \text { limonene }(11.8 \%) \\
\text { 10-epi- } \gamma \text {-eudesmol }(10.6 \%) \text {, maaliol } \\
(6.2 \%)\end{array}$ & $\begin{array}{c}\text { Acaricidal (Tetranychus urticae, Fumigation } \mathrm{LC}_{50} 1.79 \mu \mathrm{L} / \mathrm{L} ; \\
\text { residual contact } \mathrm{LC}_{50} 21.90 \mu \mathrm{L} / \mathrm{L} \text { ) }\end{array}$ & [42] \\
\hline E. langsdorffi & $\begin{array}{l}\text { Brasília, Distrito } \\
\text { Federal, Brazil }\end{array}$ & Fruit (HD) & $\begin{array}{c}\text { 10-epi- } \gamma \text {-eudesmol }(35.7 \%), \\
\text { 1,10-di-epi-cubenol }(15.6 \%), \\
\text { caryophyllene oxide }(7.5 \%), \\
\text { epi-longipinanol }(7.3 \%), \\
\text { isolongifolan-7- } \alpha \text {-ol }(7.1 \%)\end{array}$ & $\begin{array}{c}\text { Acaricidal (Tetranychus urticae, Fumigation } \mathrm{LC}_{50} 3.06 \mu \mathrm{L} / \mathrm{L} ; \\
\text { residual contact } \mathrm{LC}_{50} 12.25 \mu \mathrm{L} / \mathrm{L} \text { ) }\end{array}$ & [42] \\
\hline E. multicostata & $\begin{array}{l}\text { Dom Pedro de } \\
\text { Alcântara, Rio Grande } \\
\text { do Sul, Brazil }\end{array}$ & Leaf (HD) & $\begin{array}{l}\alpha \text {-pinene }(16.1 \%) \text {, spathulenol }(10.7 \%) \\
\text { epi-globuol }(7.8 \%), \beta \text {-pinene }(7.3 \%)\end{array}$ & - & [32] \\
\hline E. patrisii & Maracanã, Pará, Brazil & Leaf (HD) & $\begin{array}{c}\text { trans-cadin-1,4-diene }(16.5 \%), \\
\text { trans-muurola-3,5-diene }(13.3 \%), \\
\text { E-caryophyllene }(11.1 \%), \alpha \text {-cubebene } \\
(9.8 \%)\end{array}$ & - & [25] \\
\hline E. patrisii & $\begin{array}{l}\text { São Geraldo do } \\
\text { Araguaia, Pará, Brazil }\end{array}$ & $\begin{array}{l}\text { Aerial parts } \\
\quad(\mathrm{HD})\end{array}$ & $\begin{array}{c}\text { 2E,6E-Farnesol }(34.5 \%), 2 E, 6 Z \text {-Farnesol } \\
(23.2 \%), \\
\text { caryophylla-4(12)-8(13)-dien-5ß-ol } \\
(15.6 \%)\end{array}$ & $\begin{array}{c}\text { Antioxidant, DPPH assay }(40.9 \%, 111.2 \mathrm{mgTE} / \mathrm{mL}, \\
91.3 \mathrm{mgBHAE} / \mathrm{mL}) \\
\text { Cytotoxic }(\mathrm{HCT}-116 \text { human colorectal carcinoma, } \\
\mathrm{IC}_{50} 16.4 \mu \mathrm{g} / \mathrm{mL} ; \text { MRC5 human Fibroblast } \\
\mathrm{IC}_{50} 18.1 \mu \mathrm{g} / \mathrm{mL} ; \mathrm{AGP}-01 \text { human gastric adenocarcinoma, } \\
\mathrm{IC}_{50}>25 \mu \mathrm{g} / \mathrm{mL} \text {; SKMEL-19 human melanoma, } \\
\left.\mathrm{IC}_{50}>25 \mu \mathrm{g} / \mathrm{mL}\right)\end{array}$ & [37] \\
\hline E. pitanga & $\begin{array}{l}\text { Manuel Viana, Rio } \\
\text { Grande do Sul, Brazil }\end{array}$ & Leaf (HD) & $\begin{array}{c}\text { germacrene } \mathrm{D}(29.3 \%), \\
\text { bicyclogermacrene }(22.4 \%), E-\beta \text {-ocimene } \\
(10.5 \%), \text {-caryophyllene }(5.1 \%)\end{array}$ & - & [32] \\
\hline E. platysema & $\begin{array}{l}\text { Blumenau, Santa } \\
\text { Catarina, Brazil }\end{array}$ & Leaf (HD) & $\begin{array}{c}\beta \text {-selinene }(17.9 \%) \text {, allo-aromadendrene } \\
(12.6 \%), \\
\text { 7-epi- } \alpha \text {-selinene }(10.4 \%)\end{array}$ & - & [27] \\
\hline
\end{tabular}


Table A1. Cont.

\begin{tabular}{|c|c|c|c|c|c|}
\hline Species & Occurrence & Essential Oil & Primary Components $(>5 \%)$ & Essential Oil Bioactivity & Ref. \\
\hline E. pluriflora & $\begin{array}{l}\text { Aparados da Serra, } \\
\text { Rio Grande do Sul, } \\
\text { Brazil }\end{array}$ & Leaf (HD) & $\begin{array}{l}\text { E-nerolidol }(24.6 \%), \alpha \text {-pinene }(24.0 \%), \\
1,8 \text {-cineole }(12.7 \%), \alpha \text {-terpineol }(5.8 \%)\end{array}$ & - & [27] \\
\hline E. polystachya & $\begin{array}{l}\text { Parauapebas, Pará, } \\
\text { Brazil }\end{array}$ & $\begin{array}{l}\text { Aerial parts } \\
\quad(\mathrm{HD})\end{array}$ & $\begin{array}{c}\text { germacrene } \mathrm{D}(18.4 \%), \text { ishwarane } \\
(15.7 \%), \\
\text { 7-epi- } \alpha \text {-selinene }(7.5 \%) \\
\text { bicyclogermacrene }(5.1 \%) \\
\alpha \text {-ylangene }(5.0 \%)\end{array}$ & $\begin{array}{c}\text { Antioxidant, DPPH assay }(11.5 \%) \\
\text { Cytotoxic (HCT-116 human colorectal carcinoma, } \\
\mathrm{IC}_{50} 10.3 \mu \mathrm{g} / \mathrm{mL} ; \mathrm{MRC} 5 \text { human fibroblast } \\
\mathrm{IC}_{50}>25 \mu \mathrm{g} / \mathrm{mL} ; \mathrm{AGP}-01 \text { human gastric adenocarcinoma, } \\
\mathrm{IC}_{50}>25 \mu \mathrm{g} / \mathrm{mL} \text {; SKMEL-19 human melanoma, } \\
\left.\mathrm{IC}_{50}>25 \mu \mathrm{g} / \mathrm{mL}\right)\end{array}$ & [37] \\
\hline E. protenta & Maracanã, Pará, Brazil & Leaf (HD) & $\begin{array}{c}\text { germacrene } \mathrm{D}(15.1 \%), \beta \text {-elemene } \\
(12.8 \%), \\
\delta \text {-cadinene }(9.3 \%), E \text {-caryophyllene } \\
(8.3 \%), \text { bicyclogermacrene }(5.9 \%), \\
\alpha \text {-cadinol }(5.5 \%)\end{array}$ & - & [25] \\
\hline E. protenta & $\begin{array}{l}\text { Santarém Novo, Pará, } \\
\text { Brazil }\end{array}$ & Leaf (HD) & $\begin{array}{l}\text { dimethylxanthoxylin }(73.2 \%) \text {, limonene } \\
\qquad(5.9 \%)\end{array}$ & - & [23] \\
\hline E. protenta & $\begin{array}{c}\text { Santarém Novo, Pará, } \\
\text { Brazil }\end{array}$ & Leaf (HD) & dimethylxanthoxylin (83.0\%) & - & [23] \\
\hline E. protenta & $\begin{array}{l}\text { Santarém Novo, Pará, } \\
\text { Brazil }\end{array}$ & Leaf (HD) & $\begin{array}{c}\text { selin-11-en- } 4 \alpha \text {-ol }(18.3 \%), \beta \text {-elemene } \\
(16.9 \%), \\
\beta \text {-selinene }(5.6 \%), \delta \text {-cadinene }(5.5 \%), \\
\gamma \text {-selinene }(5.1 \%)\end{array}$ & - & [23] \\
\hline E. protenta & $\begin{array}{l}\text { Magalhães Barata, } \\
\text { Pará, Brazil }\end{array}$ & Leaf (HD) & $\begin{array}{c}\text { selin-11-en-4 } \alpha \text {-ol }(14.4 \%), \beta \text {-elemene } \\
(12.3 \%), \\
\alpha \text {-selinene }(6.5 \%), \text { cubenol }(5.7 \%)\end{array}$ & - & [23] \\
\hline E. protenta & Maracanã, Pará, Brazil & Leaf (HD) & $\begin{array}{c}\beta \text {-elemene }(9.2 \%) \text {, germacrene D }(7.8 \%) \text {, } \\
\alpha \text {-cadinol }(8.1 \%)\end{array}$ & - & [23] \\
\hline E. protenta & Maracanã, Pará, Brazil & Leaf (HD) & $\begin{array}{c}\text { germacrene } \mathrm{D}(15.1 \%), \\
\text { bicyclogermacrene }(11.8 \%), \\
\delta \text {-cadinene }(5.8 \%), \alpha \text {-copaene }(5.1 \%), \\
E \text {-caryophyllene }(5.1 \%)\end{array}$ & - & [23] \\
\hline
\end{tabular}


Table A1. Cont.

\begin{tabular}{|c|c|c|c|c|c|}
\hline Species & Occurrence & Essential Oil & Primary Components $(>5 \%)$ & Essential Oil Bioactivity & Ref \\
\hline E. protenta & Maracanã, Pará, Brazil & Leaf (HD) & $\begin{array}{c}\delta \text {-cadinene }(15.4 \%) \text {, germacrene D } \\
(11.5 \%), \delta \text {-elemene }(8.5 \%), \\
\text { E-caryophyllene }(7.9 \%), \alpha \text {-copaene } \\
(6.2 \%)\end{array}$ & - & {$[23]$} \\
\hline E. protenta & $\begin{array}{l}\text { Algodoal island, } \\
\text { Maracanã, Pará, Brazil }\end{array}$ & Leaf (HD) & $\begin{array}{c}\text { germacrene } \mathrm{D}(15.6 \%), \delta \text {-cadinene }(8.5 \%) \\
\alpha \text {-cadinol }(6.9 \%), \text { bicyclogermacrene } \\
(6.8 \%), \tau \text {-muurolol }(5.9 \%) \\
E \text {-caryophyllene }(5.7 \%)\end{array}$ & - & [23] \\
\hline E. punicifolia & $\begin{array}{c}\text { Serra Negra, } \\
\text { Pernambuco, Brazil }\end{array}$ & Leaf (HD) & $\begin{array}{c}\text { linalool (44.0\%), E-caryophyllene }(22.7 \%) \text {, } \\
\alpha \text {-terpineol }(8.8 \%)\end{array}$ & - & [43] \\
\hline E. punicifolia & $\begin{array}{l}\text { Brejo da Madre de } \\
\text { Deus, Pernambuco, } \\
\text { Brazil }\end{array}$ & Leaf (HD) & $\begin{array}{c}\text { linalool (61.2\%), E-caryophyllene }(16.2 \%) \text {, } \\
\alpha \text {-terpineol }(6.7 \%)\end{array}$ & - & [43] \\
\hline E. punicifolia & Maracanã, Pará, Brazil & Leaf (HD) & $\begin{array}{c}\text { E-caryophyllene }(9.9 \%), \\
\text { bicyclogermacrene }(8.7 \%), \\
\text { E- } \beta \text {-ocimene }(5.5 \%) \text {, germacrene D }(5.4 \%)\end{array}$ & - & [25] \\
\hline E. punicifolia & $\begin{array}{l}\text { Macaé, Rio de Janeiro, } \\
\text { Brazil }\end{array}$ & Leaf (HD) & $\begin{array}{c}\alpha \text {-cadinol }(10.6 \%), 10-e p i-\gamma \text {-eudesmol } \\
(10.2 \%), \text { paradisiol }(9 ; 0 \%) \\
\text { 7-epi- } \alpha \text {-selinene }(6.8 \%)\end{array}$ & - & [28] \\
\hline E. pyriformis & $\begin{array}{l}\text { Porto Alegre, Rio } \\
\text { Grande do Sul, Brazil }\end{array}$ & Leaf (HD) & $\begin{array}{c}\alpha \text {-cadinol }(14.0 \%), \delta \text {-cadinene }(12.4 \%), \\
\tau \text {-cadinol }(11.9 \%), \text { bicyclogermacrene } \\
(10.2 \%)\end{array}$ & - & {$[30]$} \\
\hline E. pyriformis & $\begin{array}{l}\text { Curitiba, Paraná, } \\
\text { Brazil }\end{array}$ & Leaf $(\mathrm{HD})^{\mathrm{b}}$ & $\begin{array}{c}\beta \text {-pinene }(0.0-25.7 \%) \text {, limonene } \\
(0.2-22.0 \%) \text {, caryophyllene oxide } \\
(3.9-21.3 \%) \\
\text { 1,8-cineole }(0.6-14.7 \%)\end{array}$ & - & {$[44]$} \\
\hline E. pyriformis & $\begin{array}{l}\text { Curitiba, Paraná, } \\
\text { Brazil }\end{array}$ & Flower (HD) & $\begin{array}{c}\text { E-caryophyllene }(22.8 \%), \text { germacrene D } \\
(15.3 \%), \text { bicyclogermacrene }(8.4 \%), \\
\alpha \text {-cadinol }(7.2 \%), \text { spathulenol }(6.8 \%)\end{array}$ & - & [44] \\
\hline E. pyriformis & $\begin{array}{l}\text { Curitiba, Paraná, } \\
\text { Brazil }\end{array}$ & Fruits (HD) & $\begin{array}{c}\text { caryophyllene oxide }(16.2 \%) \text {, limonene } \\
(12.4 \%), \\
\alpha \text {-terpineol }(5.4 \%), \alpha \text {-cadinol }(5.4 \%)\end{array}$ & - & {$[44]$} \\
\hline
\end{tabular}


Table A1. Cont.

\begin{tabular}{|c|c|c|c|c|c|}
\hline Species & Occurrence & Essential Oil & Primary Components $(>5 \%)$ & Essential Oil Bioactivity & Ref. \\
\hline E. ramboi & $\begin{array}{l}\text { Torres, Rio Gande do } \\
\quad \text { Sul, Brazil }\end{array}$ & Leaf (HD) & $\begin{array}{c}\beta \text {-elemene }(10.6 \%), \text { bicyclogermacrene } \\
(9.7 \%) \\
\text { E-caryophyllene }(6.2 \%)\end{array}$ & - & [27] \\
\hline E. repanda & $\begin{array}{l}\text { Porto Rico, Paraná, } \\
\text { Brazil }\end{array}$ & Leaf (HD) & $\begin{array}{c}\text { E-caryophyllene }(16.3 \%), \alpha \text {-humulene } \\
(10.2 \%), \text { bicyclogermacrene }(9.4 \%) \\
\text { germacrene D }(7.5 \%) \\
\beta \text {-elemene }(7.3 \%)\end{array}$ & - & [61] \\
\hline E. selloi & $\begin{array}{l}\text { Rio de Janeiro, Rio de } \\
\text { Janeiro, Brazil }\end{array}$ & Leaf $(\mathrm{HD})^{\mathrm{b}}$ & $\begin{array}{c}\text { bicyclogermacrene }(15.2-24.3 \%), \\
\text { germacrene D }(5.7-18.7 \%), \\
\text { E-caryophyllene }(6.7-12.5 \%) \\
\text { viridiflorol }(3.5-9.1 \%)\end{array}$ & - & [26] \\
\hline E. speciosa & $\begin{array}{l}\text { Itapuã, Rio Grande do } \\
\text { Sul, Brazil }\end{array}$ & Leaf (HD) & $\begin{array}{c}\alpha \text {-pinene }(47.3 \%) \text {, limonene }(23.0 \%), \\
\gamma \text {-terpinene }(2.5 \%)\end{array}$ & - & [32] \\
\hline E. stictopetala & $\begin{array}{l}\text { São Luis, Maranhão, } \\
\text { Brazil }\end{array}$ & Leaf (HD) & $\begin{array}{c}\gamma \text {-elemene }(17.48 \%), E \text {-caryophyllene } \\
(16.46 \%), \text { bicyclogermacrene }(8.11 \%), \\
\beta \text {-pinene }(7.08 \%), \text { germacrene D }(5.64 \%)\end{array}$ & Larvicidal (Aedes aegypti, LC 50230 g/mL) & [63] \\
\hline E. stigmatosa & $\begin{array}{l}\text { Peruibe, São Paulo, } \\
\text { Brazil }\end{array}$ & Leaf (HD) & physeteric acid (90.5\%) & - & [62] \\
\hline E. stipitata & $\begin{array}{l}\text { São Miguel island, } \\
\text { Açores, Portugal }\end{array}$ & Leaf (HD) & $\begin{array}{c}\text { E-caryophyllene }(22.7 \%), \text { caryophyllene } \\
\text { oxide }(15.4 \%), \alpha \text {-pinene }(14.1 \%), \\
4,8-\alpha \text {-epoxy-caryophyllene }(10.9 \%)^{\text {a }}\end{array}$ & $\begin{array}{c}\text { Antibacterial, agar diffusion assay (Staphylococcus aureus, } \\
14 \mathrm{~mm} ; \text { Pseudomonas aeruginosa, } 11 \mathrm{~mm} \text {; } \\
\text { Listeria monocytogenes, } 12 \mathrm{~mm} \text { ) }\end{array}$ & [77] \\
\hline E. stipitata & $\begin{array}{l}\text { Recife, Pernambuco, } \\
\text { Brazil }\end{array}$ & Fruit (SPE) & $\begin{array}{c}\text { germacrene D }(38.3 \%), \beta \text {-pinene }(15.2 \%), \\
\alpha \text {-pinene }(10.4 \%), \mathrm{NI}(12.6 \%)\end{array}$ & - & [90] \\
\hline E. stipitata & $\begin{array}{l}\text { Florencia-Caquetá, } \\
\text { Colombia }\end{array}$ & Fruit (SD) & limonene $(81.0 \%)$, myrcene $(5.5 \%)$ & - & [91] \\
\hline E. sulcata & $\begin{array}{l}\text { Restinga de } \\
\text { Jurubatiba, Rio de } \\
\text { Janeiro, Brazil }\end{array}$ & Leaf (HD) & $\begin{array}{l}\text { E-caryophyllene }(24.6 \%), \alpha \text {-pinene } \\
(17.2 \%), \beta \text {-pinene }(10.9 \%), 1,8 \text {-cineole } \\
(5.6 \%), \alpha \text {-humulene }(5.1 \%)\end{array}$ & $\begin{array}{l}\text { Enzyme inhibitory (acetylcholinesterase, } \mathrm{IC}_{50} 4.66 \mu \mathrm{g} / \mathrm{mL} \text { ); } \\
\text { Insecticidal (Dysdercus peruvianus and Oncopeltus fasciatus) }\end{array}$ & $\begin{array}{l}{[45,} \\
46]\end{array}$ \\
\hline
\end{tabular}


Table A1. Cont.

\begin{tabular}{|c|c|c|c|c|c|}
\hline Species & Occurrence & Essential Oil & Primary Components $(>5 \%)$ & Essential Oil Bioactivity & Ref. \\
\hline E. sulcata & $\begin{array}{l}\text { Jureia, São Paulo, } \\
\text { Brazil }\end{array}$ & Leaf (HD) & $\begin{array}{c}\alpha \text {-pinene }(34.2 \%), E \text {-caryophyllene } \\
(15.0 \%) \text {, globulol }(11.8 \%) \text {, spathulenol } \\
(7.0 \%)\end{array}$ & - & [32] \\
\hline E. sulcata & $\begin{array}{l}\text { Restinga de } \\
\text { Jurubatiba, Rio de } \\
\text { Janeiro, Brazil }\end{array}$ & Fine stem (HD) & $\begin{array}{c}\text { E-caryophyllene }(18.8 \%), \text { spathulenol } \\
(8.8 \%) \text {, calamenene }(7.0 \%), \gamma \text {-cadinene } \\
(5.8 \%), \\
\alpha \text {-humulene }(5.6 \%), \text { caryophyllene oxide } \\
(5.6 \%)\end{array}$ & - & [46] \\
\hline E. sulcata & $\begin{array}{l}\text { Macaé, Rio de Janeiro, } \\
\text { Brazil }\end{array}$ & Leaf (HD) & $\begin{array}{c}\text { 1,8-cineole }(19.0 \%), \alpha \text {-pinene }(16.9 \%), \\
\beta \text {-pinene }(14.5 \%), \text { caryophyllene oxide } \\
(9.8 \%)\end{array}$ & - & [28] \\
\hline E. triquetra & $\begin{array}{l}\text { Pueblo Hondo, } \\
\text { Táchira, Venezuela }\end{array}$ & Leaf (HD) & $\begin{array}{l}\text { linalool }(17.5 \%), \text { limonene }(16.9 \%), \\
\alpha \text {-pinene }(11.6 \%), \beta \text {-pinene }(8.7 \%)\end{array}$ & Larvicidal (Aedes aegypti, $\mathrm{LC}_{50} 64.8$ ppm) & [65] \\
\hline E. uruguayensis & $\begin{array}{l}\text { Torres, Rio Grande do } \\
\text { Sul, Brazil }\end{array}$ & Leaf (HD) & $\begin{array}{c}\alpha \text {-pinene }(23.5 \%), \beta \text {-pinene }(11.8 \%), \\
\text { E-caryophyllene }(9.5 \%), \text { caryophyllene } \\
\text { oxide }(6.4 \%)\end{array}$ & - & [27] \\
\hline E. uniflora & $\begin{array}{l}\text { Pelotas, Rio Grande } \\
\text { do Sul, Brazil }\end{array}$ & Leaf (HD) & $\begin{array}{c}\text { germacrene B }(21.2 \%), \\
\text { selin-1,3,7-(11)-trien-8-one epoxide } \\
(19.3 \%), \text { E-caryophyllene }(12.6 \%) \\
\text { germacrene A }(11.6 \%) \text {, germacrene D } \\
(11.4 \%) \text {, selina-1,3,7-(11)-trien-8-one } \\
(9.7 \%)\end{array}$ & $\begin{array}{l}\text { Antimicrobial, agar diffusion assay and broth dilution } \\
\text { assay (Staphylococcus aureus, MIC } 800 \mu \mathrm{g} / \mathrm{mL} \text {; Listeria } \\
\text { monocytogenes, MIC } 1040 \mu \mathrm{g} / \mathrm{mL} \text {; Candida lipolytica, } \\
\text { MIC } 93.7 \mu \mathrm{g} / \mathrm{mL} \text {; C. guilliermondii, MIC } 109.4 \mu \mathrm{g} / \mathrm{mL} \text { ). } \\
\text { Antioxidant (DPPH radical scavenging assay, } \\
\left.\text { IC }_{50} 833 \mu \mathrm{g} / \mathrm{mL} \text {; ABTS IC } 508.1 \mu \mathrm{g} / \mathrm{mL}\right) \\
\text { Hepatoprotective effect in rats }\end{array}$ & $\begin{array}{l}{[57,} \\
88]\end{array}$ \\
\hline E. uniflora & $\begin{array}{l}\text { São Lourenço do Sul, } \\
\text { Rio Grande do Sul, } \\
\text { Brazil }\end{array}$ & Leaf (HD) & $\begin{array}{c}\text { NI (38.28\%), E-caryophyllene }(8.18 \%), \\
\text { spathulenol (7.71\%), } \\
\text { 9,10-dehydro-iso-longifolene }(6.21 \%), \\
\text { viridiflorol }(5.78 \%), \\
\text { allo-aromadendrene }(5.66 \%), \\
\text { dihydro-cis- } \alpha \text {-copaene-8-ol }(5.24 \%), \\
\delta \text {-cadinene }(5.19 \%), \tau \text {-cadinol }(5.08 \%)\end{array}$ & $\begin{array}{l}\text { Antibacterial, broth dilution assay (Enterobacter aerogenes } \\
\text { MIC 3.125\%; Salmonella typhimurium (MIC 3.125\%) }\end{array}$ & [78] \\
\hline
\end{tabular}


Table A1. Cont.

\begin{tabular}{|c|c|c|c|c|c|}
\hline Species & Occurrence & Essential Oil & Primary Components $(>5 \%)$ & Essential Oil Bioactivity & Ref. \\
\hline E. uniflora & $\begin{array}{l}\text { São Luís, Maranhão, } \\
\text { Brazil }\end{array}$ & Leaf (HD) & $\begin{array}{c}\text { curzerene }(47.3 \%), \gamma \text {-elemene }(14.2 \%), \\
\text { trans- } \beta \text {-elemenone }(10.4 \%), \beta \text {-elemene } \\
(5.5 \%)\end{array}$ & $\begin{array}{c}\text { Antileishmanial (L. amazonensis promastigotes, } \\
\mathrm{IC}_{50} 3.04 \mu \mathrm{g} / \mathrm{mL} \text {; L. amazonensis amastigotas, } \\
\left.\mathrm{IC}_{50} 1.92 \mu \mathrm{g} / \mathrm{mL}\right)\end{array}$ & [47] \\
\hline E. uniflora & $\begin{array}{l}\text { Osasco, São Paulo, } \\
\text { Brazil }\end{array}$ & Leaf (SD) & $\begin{array}{c}\text { atractilone }(26.78 \%) \text {, curzerene }(17.96 \%) \text {, } \\
\text { germacrene B }(9.31 \%)\end{array}$ & $\begin{array}{l}\text { Antimicrobial, agar diffusion assay and broth dilution } \\
\text { assay (Streptococcus equi, MIC } 7500 \mu \mathrm{g} / \mathrm{mL} \text {; Staphylococcus } \\
\text { epidermis, MIC } 7500 \mu \mathrm{g} / \mathrm{mL} \text {; Candida dubliniensis, } \\
\text { MIC } 230 \mu \mathrm{g} / \mathrm{mL} \text {; C. tropicalis, MIC } 900 \mu \mathrm{g} / \mathrm{mL} \text {; C. albicans, } \\
\text { MIC } 1800 \mu \mathrm{g} / \mathrm{mL} ; \text { C. glabrata, MIC } 930 \mu \mathrm{g} / \mathrm{mL} \text {; C. } \\
\text { parapsilosis, MIC } 3750 \mu \mathrm{g} / \mathrm{mL} \text { C. grubii serotype A, MIC } \\
450 \mu \mathrm{g} / \mathrm{mL} \text {; C. gattii serotype C, MIC } 1800 \mu \mathrm{g} / \mathrm{mL} \text {; C. gattii } \\
\text { serotype B, MIC } 220 \mu \mathrm{g} / \mathrm{mL} \text {; C. neoformans serotype D, } \\
\text { MIC } 110 \mu \mathrm{g} / \mathrm{mL} \text {; Saccharomyces cerevisiae, MIC } 220 \mu \mathrm{g} / \mathrm{mL})\end{array}$ & [51] \\
\hline E. uniflora & $\begin{array}{l}\text { Águas de Santa } \\
\text { Bárbara, São Paulo, } \\
\text { Brazil }\end{array}$ & Leaf (SD) & $\begin{array}{c}\text { selina-1,3,7-(11)-trien-8-one }(34.0 \%) \text {, } \\
\text { selina-1,3,7-(11)-trien-8-one epoxide } \\
\text { (17.0\%), germacrene B }(10.5 \%) \text {, curzerene } \\
(5.5 \%), \text { E-caryophyllene }(5.0 \%)\end{array}$ & - & [53] \\
\hline E. uniflora & $\begin{array}{l}\text { Botucatu, São Paulo, } \\
\text { Brazil }\end{array}$ & Leaf (HD) & $\begin{array}{l}\text { selina-1,3,7-(11)-trien-8-one (30.1\%), } \\
\text { selina-1,3,7-(11)-trien-8-one epoxide } \\
(21.89 \%), E \text {-caryophyllene }(6.1 \%)\end{array}$ & $\begin{array}{l}\text { Antibacterial, broth dilution assay (Staphylococcus aureus, } \\
\text { MIC 55,600.0 } \mathrm{g} / \mathrm{mL} \text {; Staphylococcus aureus - methicillin } \\
\text { resistant, MIC 56,000.0 } \mu \mathrm{g} / \mathrm{mL} \text {; Staphylococcus aureus - } \\
\text { methicillin sensitive, MIC 50,800.0 } \mu \mathrm{g} / \mathrm{mL} \text {; Salmonella spp., } \\
\text { MIC 92,400.0 } \mu \mathrm{g} / \mathrm{mL} \text {; Salmonella enteritidis, } \\
\text { MIC 92,400.0 } \mu \mathrm{g} / \mathrm{mL} \text { Salmonella typhimurium, } \\
\text { MIC } 92,400.0 \mu \mathrm{g} / \mathrm{mL} ; \text { Escherichia coli, MIC } 84,300.0 \mu \mathrm{g} / \mathrm{mL} \text {; } \\
\text { Pseudomonas aeruginosa, MIC } 92,400.0 \mu \mathrm{g} / \mathrm{mL} \text { ) }\end{array}$ & [76] \\
\hline E. uniflora & $\begin{array}{l}\text { Seropédica, Rio de } \\
\text { Janeiro, Brazil }\end{array}$ & $\begin{array}{l}\text { Young leaf } \\
\text { (HD) }\end{array}$ & $\begin{array}{c}\text { germacrone }(37.86 \%) \text {, curzerene }(16.6 \%) \text {, } \\
\text { germacrene B }(13.59 \%) \text {, E-caryophyllene } \\
(6.02 \%)\end{array}$ & - & [92] \\
\hline E. uniflora & $\begin{array}{l}\text { Seropédica, Rio de } \\
\text { Janeiro, Brazil }\end{array}$ & Old leaf (HD) & $\begin{array}{c}\text { curzerene }(22.37 \%), \text { furanodiene } \\
(18.99 \%) \text {, } \\
\text { germacrene B }(14.39 \%), \text {-caryophyllene } \\
(9.35 \%)\end{array}$ & - & [92] \\
\hline
\end{tabular}


Table A1. Cont.

\begin{tabular}{|c|c|c|c|c|c|}
\hline Species & Occurrence & Essential Oil & Primary Components $(>5 \%)$ & Essential Oil Bioactivity & Ref. \\
\hline E. uniflora & $\begin{array}{l}\text { Anápolis, Goiás, } \\
\text { Brazil }\end{array}$ & $\begin{array}{l}\text { Aerial parts } \\
\quad(\mathrm{HD})^{\mathrm{b}}\end{array}$ & $\begin{array}{c}\text { selina-1,3,7-(11)-trien-8-one (43.0\%), } \\
\text { selina-1,3,7-(11)-trien-8-one epoxide } \\
\text { (20.0-29.0\%), } \\
\text { spathulenol (7.5-10.0\%) }\end{array}$ & - & {$[54]$} \\
\hline E. uniflora & Belém, Pará, Brazil & $\begin{array}{l}\text { Aerial parts } \\
\text { (HD) }\end{array}$ & $\begin{array}{c}\text { germacrone }(32.8 \%) \text {, curzerene }(30.0 \%), \\
\text { germacrene B }(15.6 \%)\end{array}$ & - & [55] \\
\hline E. uniflora & $\begin{array}{l}\text { Santarém, Pará, } \\
\text { Brazil }\end{array}$ & Leaf (HD) & $\begin{array}{c}\text { selina-1,3,7(11)-trien-8-one }(32.6 \%), \\
\text { selina-1,3,7(11)-trien-8-one epoxide } \\
(30.4 \%), \text { E-caryophyllene }(5.4 \%) \\
\text { germacrene B }(5.0 \%)\end{array}$ & $\begin{array}{c}\text { Antioxidant, DPPH radical scavenging assay }(30.3 \% \text {, } \\
153.5 \mathrm{mg} . \mathrm{TE} / \mathrm{mL}) ; \\
\text { Antioxidant, } \beta \text {-carotene/linoleic acid assay at } 1 \mathrm{mg} / \mathrm{mL} \text {, } \\
(10.8 \%)\end{array}$ & [48] \\
\hline E. uniflora & $\begin{array}{c}\text { Belém, Pará, } \\
\text { Brazil }\end{array}$ & Leaf (HD) & $\begin{array}{l}\text { selina-1,3,7(11)-trien-8-one }(43.1 \%) \\
\text { selina-1,3,7(11)-trien-8-one epoxide } \\
\quad(21.7 \%) \text {, germacrene B }(5.9 \%)\end{array}$ & $\begin{array}{c}\text { Antioxidant, DPPH radical scavenging assay }(35.3 \% \text {, } \\
178.8 \mathrm{mg} . \mathrm{ET} / \mathrm{mL}) ; \\
\text { Antioxidant, } \beta \text {-carotene/linoleic acid assay at } 1 \mathrm{mg} / \mathrm{mL} \\
(23.0 \%) ; \\
\text { Cytotoxic (HCT- human colon carcinoma, } \mathrm{IC}_{50} \\
16.26 \mu \mathrm{g} / \mathrm{mL} ; \mathrm{MRC} 5 \text { human fibroblast } \mathrm{IC}_{50} 10.27 \mu \mathrm{g} / \mathrm{mL} ; \\
\text { AGP-01 human gastric adenocarcinoma, } \mathrm{IC}_{50} \\
12.60 \mu \mathrm{g} / \mathrm{mL} \text {; SKMEL-19 human melanoma, } \\
\left.\mathrm{IC}_{50} 12.20 \mu \mathrm{g} / \mathrm{mL}\right)\end{array}$ & [48] \\
\hline E. uniflora & $\begin{array}{c}\text { Belém, Pará, } \\
\text { Brazil }\end{array}$ & Leaf (HD) & $\begin{array}{c}\text { caryophyllene oxide }(18.1 \%), \\
\text { selina-1,3,7(11)-trien-8-one }(18.1 \%), \\
\text { selina-1,3,7(11)-trien-8-one epoxide } \\
(16.0 \%), \beta \text {-elemene }(8.9 \%), \\
\text { E-caryophyllene }(6.1 \%)\end{array}$ & $\begin{array}{c}\text { Antioxidant, DPPH assay }(45.1 \%, 228.3 \mathrm{mg} . \mathrm{ET} / \mathrm{mL}) ; \\
\text { Antioxidant, } \beta \text {-carotene/linoleic acid assay at } 1 \mathrm{mg} / \mathrm{mL} \\
(16.8 \%) ; \\
\text { Cytotoxic }(\mathrm{HCT}-116 \text { human colon carcinoma, } \\
\mathrm{IC}_{50}>25 \mu \mathrm{g} / \mathrm{mL} \text {; MRC5 human fibroblast } \\
\mathrm{IC}_{50}>25 \mu \mathrm{g} / \mathrm{mL} \text {; AGP-01 human gastric adenocarcinoma, } \\
\mathrm{IC}_{50}>25 \mu \mathrm{g} / \mathrm{mL} \text {; SKMEL-19 human melanoma, } \\
\left.\mathrm{IC}_{50}>25 \mu \mathrm{g} / \mathrm{mL}\right)\end{array}$ & [48] \\
\hline E. uniflora & Bahia, Brazil & Leaf (SPME) & $\begin{array}{c}\text { germacrene B }(9.5 \%), \gamma \text {-elemene }(8.5 \%), \\
\beta \text {-elemene }(7.4 \%), E \text {-caryophyllene } \\
(7.1 \%), \text { germacrene D }(5.5 \%), \\
\gamma \text {-muurolene }(5.3 \%), \text { germacrone }(5.1 \%)\end{array}$ & - & [58] \\
\hline
\end{tabular}


Table A1. Cont.

\begin{tabular}{|c|c|c|c|c|c|}
\hline Species & Occurrence & Essential Oil & Primary Components $(>5 \%)$ & Essential Oil Bioactivity & Ref \\
\hline E. uniflora & $\begin{array}{l}\text { Belém, Pará, } \\
\text { Brazil }\end{array}$ & Leaf (HD) & curzerene $(50.6 \%)$, germacrene B $(5.3 \%)$ & $\begin{array}{c}\text { Antioxidant, DPPH assay }(42.8 \%, 217.0 \mathrm{mg} . \mathrm{ET} / \mathrm{mL}) \\
\text { Antioxidant, } \beta \text {-carotene/linoleic acid assay at } 1 \mathrm{mg} / \mathrm{mL} \\
(20.1 \%) \\
\text { Cytotoxic }(\mathrm{HCT}-116 \text { human colon carcinoma, } \\
\mathrm{IC}_{50} 9.28 \mu \mathrm{g} / \mathrm{mL} \text {; MRC5 human fibroblast } \\
\mathrm{IC}_{50} 14.95 \mu \mathrm{g} / \mathrm{mL} \text {; AGP-01 human gastric } \\
\text { adenocarcinoma, } \mathrm{IC}_{50} 8.73 \mu \mathrm{g} / \mathrm{mL} ; \mathrm{SKMEL}-19 \text { human } \\
\left.\text { melanoma, IC } \mathrm{IC}_{50} 15.42 \mu \mathrm{g} / \mathrm{mL}\right)\end{array}$ & [48] \\
\hline E. uniflora & $\begin{array}{l}\text { Belém, Pará, } \\
\text { Brazil }\end{array}$ & Leaf $(\mathrm{HD})^{\mathrm{b}}$ & $\begin{array}{c}\text { curzerene }(34.4-53.1 \%), \text { germacrone } \\
(0.2-10.5 \%), \text { globulol }(1.5-7.4 \%) \\
\text { germacrene B }(0.1-7.5 \%), \text { spathulenol } \\
(0.5-7.0 \%), \text { viridiflorol }(0.8-6.2 \%) \\
\beta \text {-elemene }(1.8-5.8 \%)\end{array}$ & $\begin{array}{c}\text { Antioxidant, DPPH assay (42.6-64.2\%, } \\
\text { 186.9-400.3 mg.ET/g) }\end{array}$ & {$[73]$} \\
\hline E. uniflora & $\begin{array}{l}\text { Belém, Pará, } \\
\text { Brazil }\end{array}$ & Leaf (HD) & $\begin{array}{c}\text { germacrene B }(18.4 \%) \text {, curzerene }(13.4 \%), \\
\text { E-caryophyllene }(9.1 \%), \gamma \text {-elemene } \\
(7.8 \%), \\
\beta \text {-elemene }(7.4 \%)\end{array}$ & $\begin{array}{c}\text { Antioxidant, DPPH assay }(40.6 \% \text {, } 205.6 \mathrm{mg} . \mathrm{ET} / \mathrm{mL}) \\
\text { Antioxidant } \beta \text {-carotene/linoleic acid }(26.3 \%) ; \\
\text { Cytotoxic }(\mathrm{HCT}-116 \text { human colon carcinoma, } \\
\mathrm{IC}_{50}>25 \mu \mathrm{g} / \mathrm{mL} \text {; MRC5 human fibroblast } \\
\mathrm{IC} 50>25 \mu \mathrm{g} / \mathrm{mL} \text {; AGP-01 human gastric } \\
\text { adenocarcinoma, } \mathrm{IC}_{50}>25 \mu \mathrm{g} / \mathrm{ML} \text {; SKMEL-19 human } \\
\left.\text { melanoma, } \mathrm{IC}_{50}>25 \mu \mathrm{g} / \mathrm{mL}\right)\end{array}$ & [48] \\
\hline E. uniflora & Bahia, Brazil & Leaf (SPME) & $\begin{array}{c}\text { germacrene B }(9.0 \%), \gamma \text {-elemene }(8.1 \%) \\
\gamma \text {-muurolene }(7.7 \%) \text {, germacrene } \mathrm{D} \\
(6.1 \%), \beta \text {-elemene }(5.0 \%)\end{array}$ & - & {$[58]$} \\
\hline E. uniflora & Bahia, Brazil & Leaf (SPME) & $\begin{array}{c}\text { germacrene B }(9.6 \%), \beta \text {-elemene }(9.3 \%), \\
\gamma \text {-elemene }(8.0 \%), \text { germacrene D }(6.5 \%), \\
\text { E-caryophyllene }(5.2 \%), \gamma \text {-muurolene } \\
(5.0 \%)\end{array}$ & - & {$[58]$} \\
\hline E. uniflora & $\begin{array}{l}\text { Rio de Janeiro, Rio de } \\
\text { Janeiro, Brazil }\end{array}$ & Leaf (HD) & atractilone, 3-furanoeudesmene & $\begin{array}{c}\text { Antinociceptive }\left(\mathrm{ED}_{50} 218.6 \mathrm{mg} / \mathrm{kg}\right) \text { and hypothermic in } \\
\text { mouse model }\end{array}$ & {$[52]$} \\
\hline E. uniflora & $\begin{array}{l}\text { Rio de Janeiro, Rio de } \\
\text { Janeiro, Brazil }\end{array}$ & Leaf (HD) & curzerene (50.2\%), $\beta$-elemene (5.9\%) & - & {$[50]$} \\
\hline E. uniflora & Goiás, Brazil & Leaf (HD) & $\begin{array}{c}\text { germacrene B }(21.6 \%) \text {, curzerene }(20.5 \%) \text {, } \\
\text { germacrone }(17.3 \%), E \text {-caryophyllene } \\
(8.7 \%)\end{array}$ & $\begin{array}{l}\text { Antifungal, broth dilution assay (Paracoccidioides } \\
\text { brasiliensis, MIC } 500 \mu \mathrm{g} / \mathrm{mL} \text {; MFC } 500 \mu \mathrm{g} / \mathrm{mL} \text { ) }\end{array}$ & [49] \\
\hline
\end{tabular}


Table A1. Cont.

\begin{tabular}{|c|c|c|c|c|c|}
\hline Species & Occurrence & Essential Oil & Primary Components $(>5 \%)$ & Essential Oil Bioactivity & Ref. \\
\hline E. uniflora & Goiás, Brazil & Leaf (HD) & $\begin{array}{c}\text { curzerene }(42.6 \%) \text {, germacrone }(13.5 \%) \\
\text { germacrene } \mathrm{D}(8.8 \%), \text { germacrene } \mathrm{A} \\
(7.4 \%), \\
\text { E-caryophyllene }(7.0 \%)\end{array}$ & $\begin{array}{l}\text { Antifungal, broth dilution assay (Paracoccidioides } \\
\text { brasiliensis, MIC } 62.5 \mu \mathrm{g} / \mathrm{mL} \text {; MFC } 125 \mu \mathrm{g} / \mathrm{mL} \text { ) }\end{array}$ & [49] \\
\hline E. uniflora & Goiás, Brazil & Leaf (HD) & $\begin{array}{c}\text { selin-1,3,7-(11)-trien-8-one }(48.2 \%) \text {, } \\
\text { selin-1,3,7-(11)-trien-8-one epoxide } \\
(19.3 \%), \\
\text { atractilone }(11.7 \%) \text {, germacrene B }(5.9 \%)\end{array}$ & $\begin{array}{l}\text { Antifungal, broth dilution assay (Paracoccidioides } \\
\text { brasiliensis, MIC } 250 \mu \mathrm{g} / \mathrm{mL} \text {; MFC } 250 \mu \mathrm{g} / \mathrm{mL} \text { ) }\end{array}$ & [49] \\
\hline E. uniflora & $\begin{array}{l}\text { Pelotas, Rio Grande } \\
\text { do Sul, Brazil }\end{array}$ & Fruits (HD) & $\begin{array}{c}\text { hexadecanoic acid }(11.7 \%), E \text { - } \beta \text {-ocimene } \\
(7.4 \%), \\
\alpha \text {-selinene }(7.2 \%) \text {, germacrene B }(7.2 \%), \\
\text { bicyclogermacrene }(5.2 \%)\end{array}$ & Antioxidant, DPPH assay (TLC method) & [40] \\
\hline E. verticillata & $\begin{array}{l}\text { Caraguatatuba, São } \\
\text { Paulo, Brazil }\end{array}$ & Leaf (HD) & $\begin{array}{c}\text { valerianol }(28.1 \%), 10-e p i-\gamma \text {-eudesmol } \\
(12.6 \%), \\
\text { E-caryophyllene }(10.9 \%), \alpha \text {-selinene } \\
(6.1 \%), \\
\delta \text {-cadinene }(5.7 \%)\end{array}$ & Enzyme inhibitory (acetylcholinesterase, $\mathrm{IC}_{50} 67.3 \mu \mathrm{g} / \mathrm{mL}$ ) & [64] \\
\hline E. xiriricana & $\begin{array}{l}\text { Peruíbe, São Paulo, } \\
\text { Brazil }\end{array}$ & Leaf (HD) & $\begin{array}{l}\text { spathulenol }(15.4 \%), \beta \text {-pinene }(14.1 \%) \\
\text { globulol }(8.6 \%), \alpha \text {-pinene }(7.8 \%)\end{array}$ & - & [32] \\
\hline S. cumini & $\begin{array}{l}\text { Rio de Janeiro, Rio de } \\
\text { Janeiro, Brazil }\end{array}$ & Leaf (HD) & $\begin{array}{c}\alpha \text {-pinene }(22.2 \%), Z \text { - } \beta \text {-ocimene }(10.2 \%), \\
\text { E-caryophyllene }(9.45 \%), \text { limonene } \\
(7.3 \%), \\
\alpha \text {-terpineol }(7.00 \%), E-\beta \text {-ocimene }(5.88 \%), \\
\alpha \text {-humulene }(5.5 \%)\end{array}$ & $\begin{array}{l}\text { Anti-inflammatory, lipopolysaccharide-induced pleurisy } \\
\text { model, an eosinophil was inhibited in } 67 \%\end{array}$ & [66] \\
\hline S. cumini & $\begin{array}{l}\text { São Luis, Maranhão, } \\
\text { Brazil }\end{array}$ & Leaf (HD) & $\begin{array}{c}\alpha \text {-pinene }(31.85 \%), Z \text { - } \beta \text {-ocimene } \\
(28.98 \%), \\
\text { E- } \beta \text {-ocimene }(11.71 \%), \beta \text {-pinene }(5.57 \%), \\
\text { E-caryophyllene }(5.02 \%)\end{array}$ & $\begin{array}{l}\text { Antileishmanial (Leishmania amazonensis promastigotes, } \\
\left.\qquad \mathrm{IC}_{50} 60 \mu \mathrm{g} / \mathrm{mL}\right) ; \\
\left.\text { Molluscicide (Biomphalaria glabrata, } \mathrm{LC}_{50} 90 \mu \mathrm{g} / \mathrm{mL}\right)\end{array}$ & [67] \\
\hline S. cumini & Crato, Ceará, Brazil & Leaf (HD) & $\begin{array}{c}\alpha \text {-pinene }(48.1 \%), \text { E-nerolidol }(8.7 \%) \\
\text { nerol }(7.1 \%), \text { nonanol }(6.8 \%)^{a}\end{array}$ & $\begin{array}{l}\text { Antibacterial, broth dilution assay (Staphylococcus aureus, } \\
\text { MIC } 128 \mu \mathrm{g} / \mathrm{mL} \text {; Escherichia coli } \mathrm{MIC}>1024 \mu \mathrm{g} / \mathrm{mL} \text { ) }\end{array}$ & [68] \\
\hline S. cumini & Crato, Ceará, Brazil & Leaf (HD) & $\begin{array}{c}\alpha \text {-pinene }(30.0 \%), E \text { - } \beta \text {-ocimene }(26.8 \%), \\
\beta \text {-ocimene }(11.1 \%), \beta \text {-pinene }(8.3 \%), \\
\text { limonene }(6.5 \%), \beta \text {-Fenchol }(7.3 \%)^{a}\end{array}$ & - & [69] \\
\hline
\end{tabular}


Table A1. Cont.

\begin{tabular}{|c|c|c|c|c|c|}
\hline Species & Occurrence & Essential Oil & Primary Components $(>5 \%)$ & Essential Oil Bioactivity & Ref. \\
\hline S. cumini & $\begin{array}{l}\text { Juiz de Fora, Minas } \\
\text { Gerais, Brazil }\end{array}$ & Leaf (HD) & $\begin{array}{c}\alpha \text {-humulene }(25.24 \%), E \text {-caryophyllene } \\
(16.00 \%), \\
\alpha \text {-terpineol }(9.08 \%), \text { globulol }(5.23 \%)\end{array}$ & Anti-inflammatory; Antibacterial (Mycobacterium bovis) & [70] \\
\hline S. cumini & $\begin{array}{c}\text { Porto } \\
\text { Rico, Paraná, Brazil }\end{array}$ & Seed (HD) ${ }^{b}$ & $\begin{array}{c}\text { E-caryophyllene }(6.4-42.5 \%) \\
\alpha \text {-humulene }(6.6-22.2 \%), \text { caryophyllene } \\
\text { oxide }(5.3-37.3 \%), \\
\text { humulene epoxide II }(2.1-17.1 \%)\end{array}$ & - & [93] \\
\hline S. jambos & $\begin{array}{c}\text { Rio Verde, Goiás, } \\
\text { Brazil }\end{array}$ & Leaf (HD) ${ }^{b}$ & $\begin{array}{c}\text { E-caryophyllene (0-10.86\%), } \alpha \text {-humulene } \\
(0.0-7.07 \%), \alpha \text {-zingiberene }(0.97-17.73 \%), \\
\text { hydroxytoluenebuthyled }(3.44-32.82 \%), \\
\text { caryophyllenyl alcohol }(1.48-17.14 \%), \\
\text { caryolan-8-ol }(0-10.75 \%) \text {, caryophyllene } \\
\text { oxide }(0-5.05 \%), \text { tujopsan-2- } \alpha \text {-ol } \\
(1.01-12.19 \%), \text { heneicosane }(1.73-18.0 \%) \text { a }\end{array}$ & - & [74] \\
\hline
\end{tabular}

$\mathrm{a}=$ The analysis is doubtful, based on known retention indices $(\mathrm{RI}), \mathrm{b}=$ seasonal study, $\mathrm{SD}=$ steam distillation, $\mathrm{HD}=$ hydrodistillation, $\mathrm{SPME}=$ solid phase microextraction, $\mathrm{NI}=$ unidentified compound, $\mathrm{IC}_{50}=$ median inhibitory concentration, $\mathrm{MIC}=$ minimum inhibitory concentration, $\mathrm{MMC}=$ minimum microbicide concentration, $\mathrm{LC} \mathrm{F}_{50}=$ median lethal concentration 


\section{Appendix B}<smiles>C=CC(=C)CCC=C(C)C</smiles><smiles>C=C/C(C)=C\CC=C(C)C</smiles><smiles>C=CC(C)=CCC=C(C)C</smiles><smiles>C=C(C)C1CC=C(C)CC1</smiles><smiles>CC1=CCC2CC1C2(C)C</smiles><smiles>C=C1CCC2CC1C2(C)C</smiles>

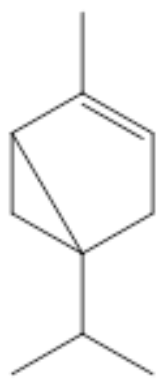

$\alpha$-thujene<smiles>C=CC(C)(O)CCC=C(C)C</smiles>

linalool<smiles>CC(C)=CCC/C(C)=C\CO</smiles>

nerol

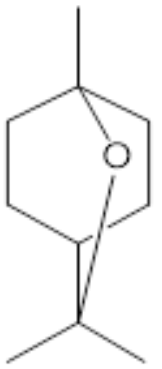

1,8-cineole

Figure A1. Major monoterpene constituents found in Eugenia and Syzygium essentials oils.<smiles>C=C1CC/C=C(/C)CC[C@@H]2C[C@@H]1CC2(C)C</smiles><smiles>CC1=CCC(C)(C)CCCC(C)=CCC1</smiles>

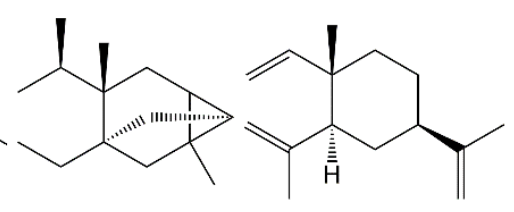<smiles>C=C[C@]1(C)CCC(C(C)C)=C[C@H]1C(=C)C</smiles>

E-caryophyllene $\alpha$-humulene ishwarane

$\beta$-elemene

$\delta$-elemene<smiles>C=CC1=CCC(C(=C)CC(CC=C(C)C)/C(C)=C2/CC[C@](C)(C=C)[C@H](C(=C)C)C2)CC1</smiles><smiles>C=C(C)CCCC(C)=C1CC=C(C)CC1</smiles><smiles>CC(C)=CCCC(C)=C1CC=C(C)CC1</smiles><smiles>CC(C)=CCC[C@H](C)[C@H]1C=CC(C)=CC1</smiles><smiles>CC(C)=CCCC1(C)CCC=C(C)C1</smiles>

$\beta$-bisabolene

E-iso- $\gamma$-bisabolene

E- $\gamma$-bisabolene

$\alpha$-zingiberene<smiles>C=C(C1CC/C2=C/CCC(C)=CCC2C1)C1CC=C2CCC(=C(C)C)C/C=C(\C)CC1C2</smiles><smiles>C=C1CCC=C2CCC(C(C)C)/C=C/C(=C)C2C1</smiles>

$\alpha$-trans-bergamotene germacrene A

germacrene B

germacrene D<smiles>C=CCCC1[C@@H](C=C(C)CCC=C2CCC=CCCC2)C1(C)C</smiles>

bicyclogermacrene<smiles>C=C(CC)C(=C)[C@@H]1CC[C@@]2(C)CCC=C(C)[C@H]2C1</smiles>

$\alpha$-selinene<smiles>C=C(C(C)CC)[C@@H]1CC[C@@]2(C)CCC=C(C)[C@H]2C1</smiles>

7-epi- $\alpha$-selinene<smiles>C=C1CCC[C@]2(C)CC[C@@H](C(=C)C)C[C@H]12</smiles>

$\beta$-selinene<smiles>C=C1CCC[C@]2(C)CCC(=C(C)C)C[C@H]12</smiles>

$\gamma$-selinene

Figure A2. Cont. 
<smiles>C=C(C)[C@@H]1CCC2=CCC[C@@H](C)[C@@]2(C)C1</smiles>

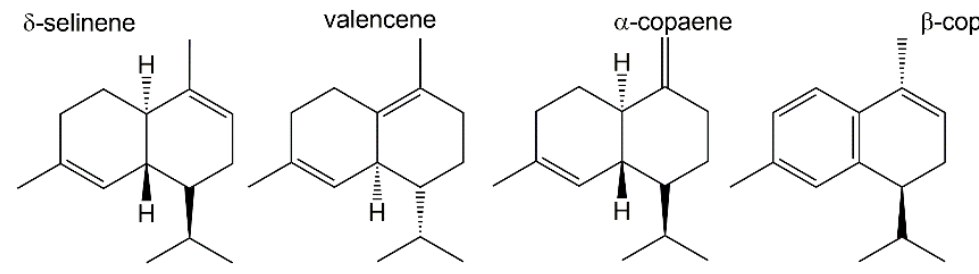<smiles>C=C1CC[C@H](C(C)C)[C@]2(C)C=C(C)CC[C@H]12</smiles>

trans-muurola-3,5-diene $\gamma$-muurolene trans-cadina-1,4-diene $\alpha$-ylangene<smiles>C=C1CCC2[C@H]([C@H]3[C@@H](C)CC[C@H]13)C2(C)C</smiles><smiles></smiles>

allo-aromadendrene

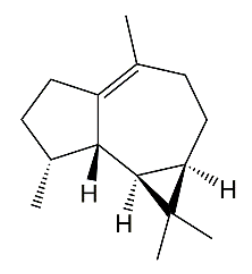

Figure A2. Major sesquiterpene hydrocarbons found in Eugenia and Syzygium essentials oils.<smiles>C=CC(C)(O)CCC=C(C)CCC=C(C)C</smiles><smiles>CC(C)=CCCC(C)=CCC(C)=CCO</smiles><smiles>C=C[C@]1(C)CC(=O)C(=C(C)C)C[C@H]1C(=C)C</smiles>

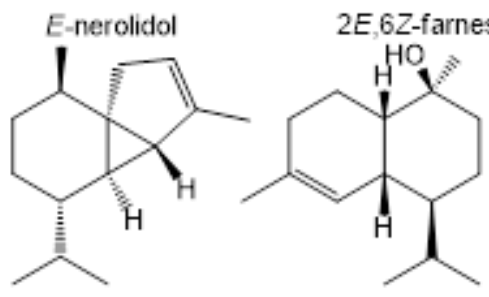

a-cubebene t-muurolol

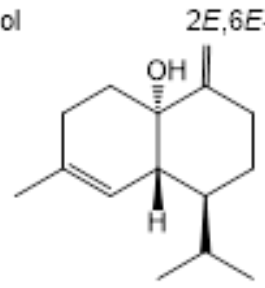<smiles>CC1=C[C@@H]2[C@H](CC1)[C@@H](O)CC[C@H]2C(C)C(=O)OC(C)C</smiles>
trans- $\beta$-elemenone<smiles>CC1=C[C@]2(C)[C@@H](C(C)C)CC[C@@H](C)[C@]2(O)CC1</smiles><smiles>CC1=C[C@H]2[C@@H](C(C)C)CC[C@@H](C)[C@]2(O)CC1</smiles><smiles>CC1=C[C@H]2[C@@H](C(C)C)CC[C@@H](C)[C@]2(O)CC1</smiles>

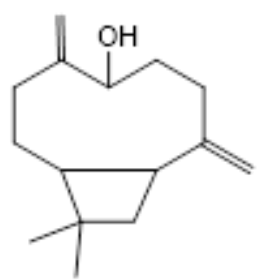

Figure A3. Cont. 

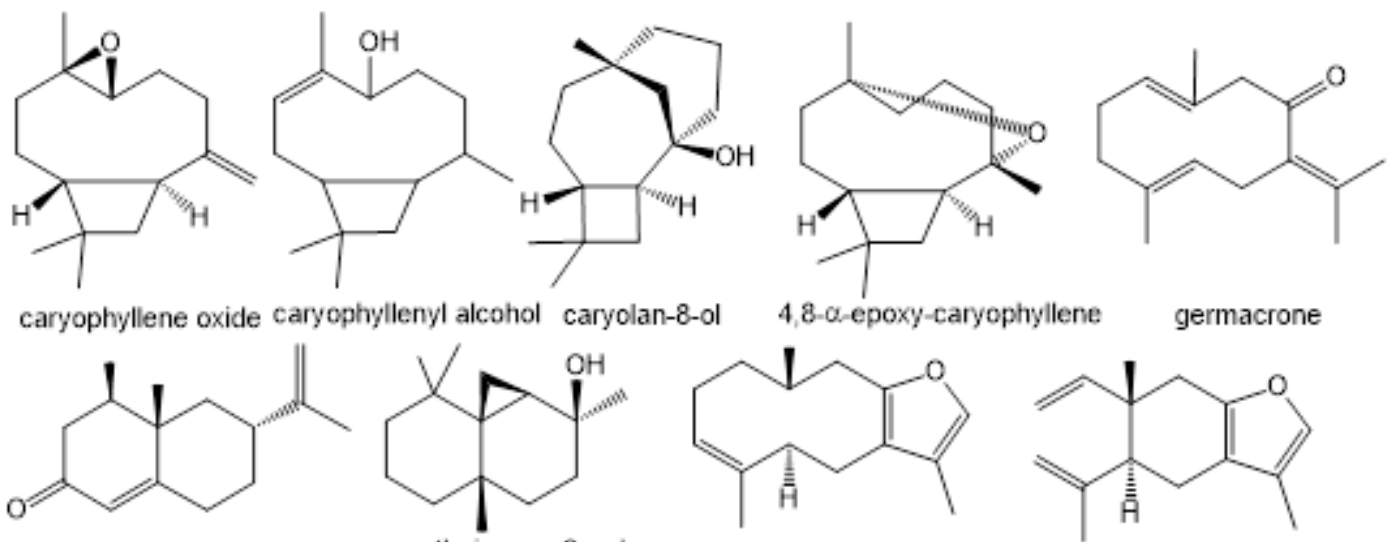

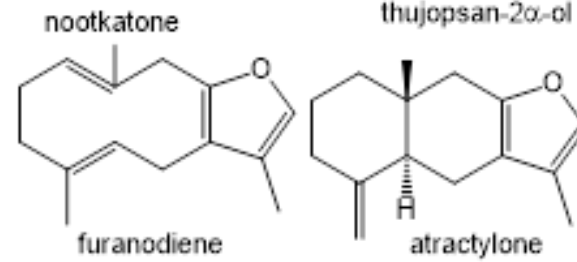<smiles>C=C(C)[C@@H]1CC[C@@]2(CC)CCC[C@H](O)[C@H]2C1</smiles><smiles>CC1=CC=C[C@]2(C)CC(=O)C(=C(C)C)C[C@@H]12</smiles><smiles>CC1=COC=C[C@]2(C)CC(=O)C(=C(C)C)C[C@@H]12</smiles><smiles>CC1CC[C@H]2[C@@H](O)CCC3C([C@H]12)C3(C)C</smiles><smiles>CC1CC[C@H]2C1C1C(CC[C@H]2O)C1(C)C</smiles>
globulol<smiles>C=C[C@]1(C)Cc2occ(C)c2C[C@H]1C(=C)C</smiles>

curzerene

selina-1,3,7-(11)-trien-8-one epoxide spathulenol viridiflorol
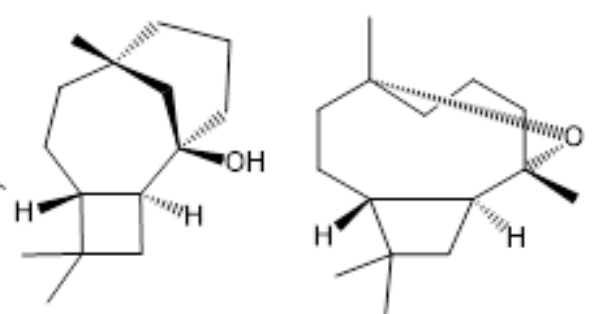<smiles>CC1=CCC(=C(C)C)C(=O)CC(C)=CC1</smiles>

caryophyllene oxide caryophyllenyl alcohol

caryolan-8-ol

4,8-a-epoxy-caryophyllene

germacrone<smiles>C=C(C)[C@@H]1CCC2=CC(=O)C[C@H](C)[C@]2(C)C1</smiles>

nootkatone

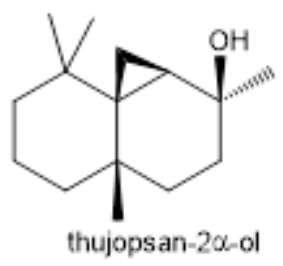

thujopsan-2 $\alpha$-ol

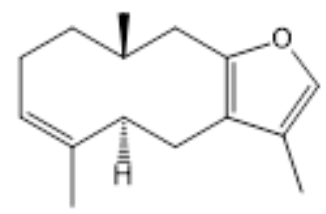

furanoeudesmene<smiles>C=C[C@]1(C)Cc2occ(C)c2C[C@H]1C(=C)C</smiles>

curzerene<smiles>C=C1CCC[C@@]2(C)Cc3occ(C)c3C[C@]12Cc1occ(C)c1C/C=C(\C)CCC/C(C)=C/C</smiles>

furanodiene<smiles>C=C(C)[C@@H]1CC[C@@]2(C)CCC[C@H](O)[C@H]2C1</smiles>

selin-11-en-4 $\alpha$-ol

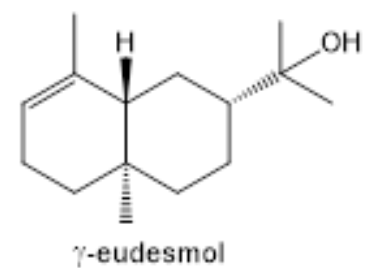

Figure A3. Cont. 
<smiles>C=C(C)[C@@H]1CC[C@@]2(C)CCC[C@@](O)(C1)[C@H]1C[C@@H](C(C)(C)O)CC[C@]1(C)C2C</smiles><smiles>CC1(C)[C@@H]2[C@@H]3[C@H](O)CCC[C@]3(C)CC[C@H]21</smiles>

1,10-epi-y-eudesmol

neo-itermedeol

valeirianol

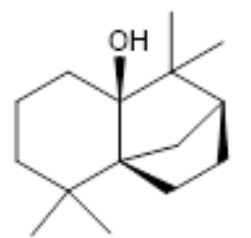<smiles>CC1=CC=C[C@]2(C)CC(=O)C(=C(C)C)C[C@@H]12</smiles><smiles>CC1=COC=C[C@]2(C)CC(=O)C(=C(C)C)C[C@H]12</smiles>

maaliol isolongifolan-7- $\alpha$-ol selina-1,3,7-(11)-trien-8-one selina-1,3,7-(11)-trien-8-one epoxide

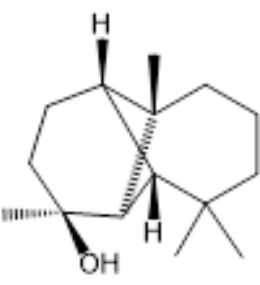

epi-longipinanol

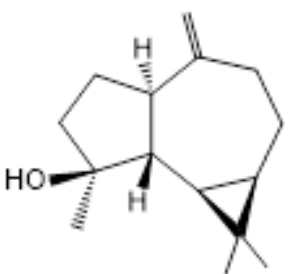

spathulenol

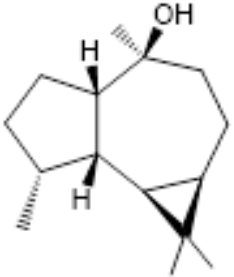

viridiflorol

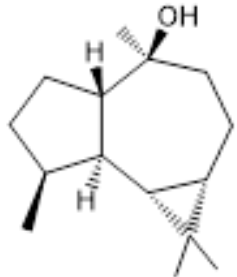

alobulol

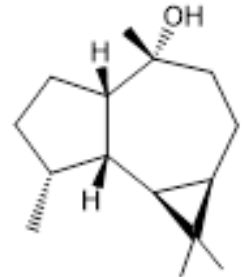

ledol

Figure A3. Major oxygenated sesquiterpenes found in Eugenia and Syzygium essentials oils.

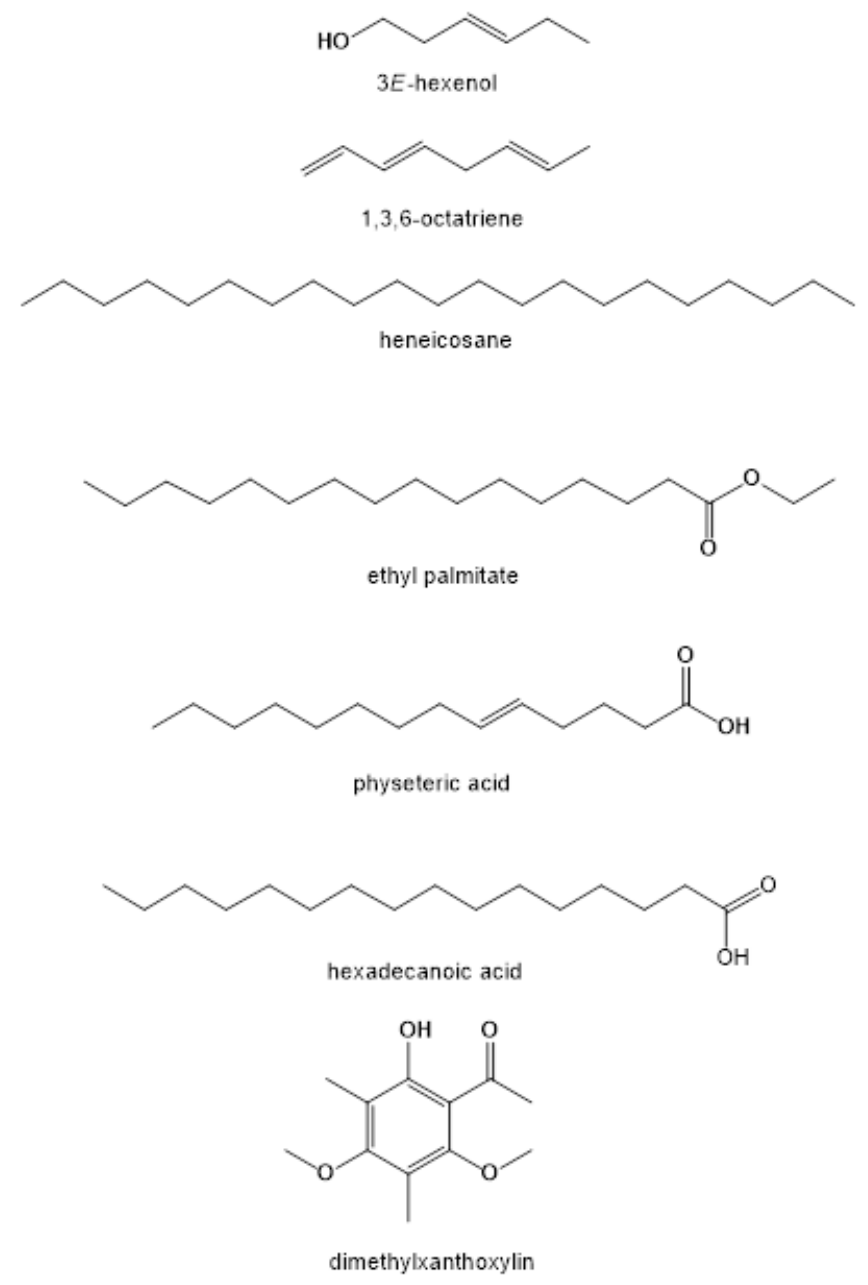

Figure A4. Other major constituents found in Eugenia and Syzygium essentials oils. 


\section{References}

1. Parnell, J.A.N.; Craven, L.A.; Biffin, E. Matters of Scale: Dealing with One of the Largest Genera of Angiosperms. In Reconstructing the Tree of Life: Taxonomy and Systematics of Species Rich Taxa; Hodkinson, T.R., Parnell, J.A.N., Eds.; Taylor and Francis: Boca Raton, IL, USA, 2007; pp. 251-273, ISBN 9780429128097.

2. THE ANGIOSPERM PHYLOGENY GROUP. An update of the Angiosperm Phylogeny Group classification for the orders and families of flowering plants: APG IV. Bot. J. Linn. Soc. 2016, 181, 1-20. [CrossRef]

3. Mazine, F.F.; Faria, J.E.Q.; Giaretta, A.; Vasconcelos, T.; Forest, F.; Lucas, E. Phylogeny and biogeography of the hyper-diverse genus Eugenia (Myrtaceae: Myrteae), with emphasis on E. sect. Umbellatae, the most unmanageable clade. TAXON 2018, 67, 752-769. [CrossRef]

4. Craven, L.; Biffin, E. An infrageneric classification of Syzygium (Myrtaceae). Blumea Biodivers. Evol. Biogeogr. Plants 2010, 55, 94-99. [CrossRef]

5. Van Der Merwe, M.M.; Van Wyk, A.E.E.; Botha, A.M. Molecular phylogenetic analysis of Eugenia L. (Myrtaceae), with emphasis on southern African taxa. Plant Syst. Evol. 2004, 251, 21-34. [CrossRef]

6. Wilson, P.G. Conspectus of the genus Eugenia (Myrtaceae) in the Philippines. Gard. Bull. Singapore. 2009, 60, 399-410.

7. Gressler, E.; Pizo, M.A.; Morellato, L.P.C. Polinização e dispersão de sementes em Myrtaceae do Brasil. Braz. J. Bot. 2006, 29, 509-530. [CrossRef]

8. Siani, A.; Sampaio, A.L.F.; Souza, M.C.; Henriques, M.G.M.O.; Ramos, M.F. Óleos essenciais: Potencial antiinflamatório. Biotecnol. Ciência e Desenvolv 2000, 16, 38-46.

9. De Queiroz, J.M.G.; Suzuki, M.C.M.; Motta, A.P.R.; Nogueira, J.M.R.; De Carvalho, E.M. Aspectos populares e científicos do uso de espécies de Eugenia como fitoterápico. Rev. Fitos 2015, 9, 87-100. [CrossRef]

10. De Souza, A.M.; De Oliveira, C.F.; Oliveira, V.B.; Betim, F.C.M.; Miguel, O.G.; Miguel, M.D. Traditional Uses, Phytochemistry, and Antimicrobial Activities of Eugenia Species - A Review. Planta Medica 2018, 84, 1232-1248. [CrossRef] [PubMed]

11. Ahmad, B.; Baider, C.; Bernardini, B. Syzygium (Myrtaceae): Monographing a taxonomic giant via 22 coordinated regional revisions. PeerJ Prepr. 2016, 4, e1930v1. [CrossRef]

12. Soh, W.K. Taxonomy of Syzygium. In The Genus Syzygium: Syzygium cumini and Other Underutilized Species; Nair, K.N., Ed.; Taylor \& Francis: New York, NY, USA, 2017; pp. 1-5. ISBN 9788578110796.

13. Myrtaceae in Lista de Espécies da Flora do Brasil. Available online: http://floradobrasil.jbrj.gov.br/ (accessed on 30 July 2020).

14. Cavalcante, P.B. Frutas Comestíveis na Amazônia; 7th ed.; Museu Paraense Emilio Goeldi: Belém, Brazil, 2010.

15. Sujanapal, P.; Kunhikannan, C. The Genus Syzygium in Western Ghats. In The Genus Syzygium: Syzygium cumini and Other Underutilized Species; Nair, K.N., Ed.; Taylor \& Francis: New York, NY, USA, 2017; pp. 15-56, ISBN 9781315118772.

16. Mala Ranghoo-Sanmukhiya, V.; Chellan, Y.; Govinden-Soulange, J.; Lambrechts, I.; Stapelberg, J.; Crampton, B.G.; Lall, N. Biochemical and phylogenetic analysis of Eugenia and Syzygium species from Mauritius. J. Appl. Res. Med. Aromat. Plants 2019, 12, 21-29. [CrossRef]

17. Lima, L.A.; Siani, A.C.; Brito, F.A.; Sampaio, A.L.F.; Henriques, M.D.G.; Riehl, C.A. Correlation of anti-inflammatory activity with phenolic content in the leaves of Syzygium cumini (1.) skeels (myrtaceae). Química Nova 2007, 30, 860-864. [CrossRef]

18. de Melo, R.R.; de Araújo, É.R.S.; da Silva, A.A.L.; Randau, K.P.; de Azevedo Ximenes, E.C.P. Características farmacobotânicas, químicas e biológicas de Syzygium malaccense (L.) Merr.\& 1. M. Perry. Rev. Bras. Farmacol 2009, 90, 298-302.

19. Sujanapal, P.; Sankaran, K.V. Syzygium aqueum (Burm. f.) Alston. In Common Plants of Maldives; Sujanapal, P., Sankaran, K.V., Eds.; Food and Agriculture Organization of the United Nations; Kerala Forest Research Institute: Bangkok, Thailand, 2016; p. 258, ISBN 9789251092958.

20. Ayyanar, M.; Subash-Babu, P. Syzygium cumini (L.) Skeels: A review of its phytochemical constituents and traditional uses. Asian Pac. J. Trop. Biomed. 2012, 2, 240-246. [CrossRef]

21. Lubes, G.; Goodarzi, M. Analysis of Volatile Compounds by Advanced Analytical Techniques and Multivariate Chemometrics. Chem. Rev. 2017, 117, 6399-6422. [CrossRef] [PubMed]

22. Stefanello, M.E.A.; Pascoal, A.C.R.F.; Salvador, M.J. Essential Oils from Neotropical Myrtaceae: Chemical Diversity and Biological Properties. Chem. Biodivers. 2011, 8, 73-94. [CrossRef] 
23. Zoghbi, M.; Guilhon, G.; Sarges, F.; Pereira, R.; Oliveira, J. Chemical variability of the volatiles from the leaves of Eugenia protenta McVaugh (Myrtaceae) growing wild in the North of Brazil. Biochem. Syst. Ecol. 2011, 39, 660-665. [CrossRef]

24. Figueiredo, P.L.B.; Fernandes, H.A.; Da Silva, A.R.C.; Alves, N.S.F.; Setzer, W.N.; Da Silva, J.K.R.; Maia, J.G.S. Variability in the Chemical Composition of Eugenia biflora Essential Oils from the Brazilian Amazon. Nat. Prod. Commun. 2019, 14, 1934578-19892439. [CrossRef]

25. Pereira, R.A.; Zoghbi, M.D.G.B.; Bastos, M.D.N.D.C. Essential Oils of Twelve Species of Myrtaceae Growing Wild in the Sandbank of the Resex Maracanã, State of Pará, Brazil. J. Essent. Oil Bear. Plants 2010, 13, 440-450. [CrossRef]

26. Defaveri, A.C.A.; Sato, A.; Borré, L.B.; Aguiar, D.L.M.; Gil, R.A.S.S.; Arruda, R.C.O.; Riehl, C.A.S. Eugenia neonitida Sobral and Eugenia rotundifolia Casar. (Myrtaceae) essential oils: Composition, seasonality influence, antioxidant activity and leaf histochemistry. J. Braz. Chem. Soc. 2011, 22, 1531-1538. [CrossRef]

27. Apel, M.A.; Limberger, R.P.; Sobral, M.; Henriques, A.T.; Ntalani, H.; Vérin, P.; Menut, C.; Bessiere, J.-M. Chemical Composition of the Essential Oils from Southern Brazilian Eugenia Species. Part III. J. Essent. Oil Res. 2002, 14, 259-262. [CrossRef]

28. Ramos, M.F.D.S.; Monteiro, S.D.S.; Da Silva, V.P.; Nakamura, M.J.; Siani, A.C. Essential Oils From Myrtaceae Species of the Brazilian Southeastern Maritime Forest (Restinga). J. Essent. Oil Res. 2010, 22, 109-113. [CrossRef]

29. Magina, M.D.A.; Dalmarco, E.M.; Wisniewski, A.; Simionatto, E.L.; Dalmarco, J.B.; Pizzolatti, M.G.; Brighente, I.M.C.; Wisniewski, A. Chemical composition and antibacterial activity of essential oils of Eugenia species. J. Nat. Med. 2009, 63, 345-350. [CrossRef] [PubMed]

30. Apel, M.A.; Sobral, M.; Schapoval, E.; Henriques, A.T.; Menut, C.; Bessiere, J.-M. Chemical Composition of the Essential Oils of Eugenia beaurepaireana and Eugenia pyriformis: Section Dichotomae. J. Essent. Oil Res. 2004, 16, 191-192. [CrossRef]

31. Magina, M.D.A.; Pietrovski, E.F.; Gomig, F.; Falkenberg, D.D.B.; Cabrini, D.A.; Otuki, M.F.; Pizzollati, M.G.; Brighente, I.M.C. Topical antiinflammatory activity and chemical composition of the epicuticular wax from the leaves of Eugenia beaurepaireana (Myrtaceae). Braz. J. Pharm. Sci. 2009, 45, 171-176. [CrossRef]

32. Apel, M.A.; Sobral, M.; Schapoval, E.; Henriques, A.T.; Menut, C.; Bessiere, J.-M. Essential Oils from Eugenia Species-Part VII: Sections Phyllocalyx and Stenocalyx. J. Essent. Oil Res. 2004, 16, 135-138. [CrossRef]

33. Moreno, P.R.H.; Lima, M.E.L.; Sobral, M.; Young, M.C.M.; Cordeiro, I.; Apel, M.A.; Limberger, R.P.; Henriques, A.T. Essential oil composition of fruit colour varieties of Eugenia brasiliensis Lam. Sci. Agricola 2007, 64, 428-432. [CrossRef]

34. Stefanello, M.; Élida, A.; Cervi, A.C.; Ito, I.Y.; Salvador, M.; Wisniewski, A.; Simionatto, E.L.; Wisniewski, A. Chemical Composition and Antimicrobial Activity of Essential Oils of Eugenia chlorophylla (Myrtaceae). J. Essent. Oil Res. 2008, 20, 75-78. [CrossRef]

35. Costa, T.R.; Fernandes, O.F.; Santos, S.D.C.; Oliveira, C.M.; Lião, L.M.; Ferri, P.H.; Paula, J.R.; Ferreira, H.D.; Sales, B.H.; Silva, M.D.R.R. Antifungal activity of volatile constituents of Eugenia dysenterica leaf oil. J. Ethnopharmacol. 2000, 72, 111-117. [CrossRef]

36. Duarte, A.R.; Naves, R.R.; Santos, S.D.C.; Seraphin, J.C.; Ferri, P.H. Genetic and environmental influence on essential oil composition of Eugenia dysenterica. J. Braz. Chem. Soc. 2010, 21, 1459-1467. [CrossRef]

37. Da Da Silva, J.K.R.; Andrade, E.H.A.; Barreto, L.H.; Da Silva, N.C.F.; Ribeiro, A.F.; Montenegro, R.C.; Maia, J.G.S. Chemical Composition of Four Essential Oils of Eugenia from the Brazilian Amazon and Their Cytotoxic and Antioxidant Activity. Medicines 2017, 4, 51. [CrossRef] [PubMed]

38. Ciarlini, J.; Marangoni, A.; Bolzan, A. Selectivity of supercritical CO2 extraction and atmospheric pressure techniques for the major volatile compounds of Eugenia involucrata leaves from Southern Brazil. Food Bioprod. Process. 2017, 106, 29-34. [CrossRef]

39. Sousa, R.M.F.; De Morais, S.A.; Vieira, R.B.; Napolitano, D.R.; Guzman, V.B.; Moraes, T.S.; Cunha, L.C.; Martins, C.H.G.; Chang, R.; De Aquino, F.J.T.; et al. Chemical composition, cytotoxic, and antibacterial activity of the essential oil from Eugenia calycina Cambess. leaves against oral bacteria. Ind. Crop. Prod. 2015, 65, 71-78. [CrossRef]

40. Marin, R.; Apel, M.A.; Limberger, R.P.; Raseira, M.C.B.; Pereira, J.F.M.; Zuanazzi, J.Â.S.; Henriques, A.T. Volatile Components and Antioxidant Activity from some Myrtaceous Fruits cultivated in Southern Brazil. Lat. Am. J. Pharm. 2008, 27, 172-177. 
41. Carneiro, N.S.; Alves, C.C.; Alves, J.M.; Egea, M.B.; Martins, C.H.G.; Silva, T.S.; Bretanha, L.C.; Balleste, M.P.; Micke, G.A.; Silveira, E.V.; et al. Chemical composition, antioxidant and antibacterial activities of essential oils from leaves and flowers of Eugenia klotzschiana Berg (Myrtaceae). Anais da Academia Brasileira de Ciências 2017, 89, 1907-1915. [CrossRef]

42. De Moraes, M.M.; Da Câmara, C.A.G.; Dos Santos, M.L.; Fagg, C.W. Essential oil composition of Eugenia langsdorffii O. Berg.: Relationships between some terpenoids and toxicity against Tetranychus urticae. J. Braz. Chem. Soc. 2012, 23, 1647-1656. [CrossRef]

43. De Oliveira, R.; Dias, I.; Câmara, C. Estudo comparativo do óleo essencial de Eugenia punicifolia (HBK) DC. de diferentes localidades de Pernambuco. Rev. Bras. de Farm. 2005, 15, 39-43. [CrossRef]

44. Stefanello, M.É.A.; Junior, A.W.; Simionatto, E.L.; Cervi, A.C. Composição Química e Variação Sazonal dos Óleos Essenciais de Eugenia pyriformis (Myrtaceae). Lat. Am. J. Pharm. 2009, 28, 449-453.

45. Gonzalez, M.S.; Lima, B.G.; Oliveira, A.F.; Nunes, D.D.; Fernandes, C.P.; Santos, M.G.; Tietbohl, L.A.; Mello, C.B.; Rocha, L.; Feder, D. Effects of essential oil from leaves of Eugenia sulcata on the development of agricultural pest insects. Rev. Bras. de Farm. 2014, 24, 413-418. [CrossRef]

46. Lima, B.G.; Tietbohl, L.A.C.; Fernandes, C.P.; Cruz, R.A.S.; da Botas, G.S.; Santos, M.G.; Silva-Filho, M.V.; Rocha, L. Chemical composition of essential oils and anticholinesterasic activity of Eugenia sulcata spring ex mart. Lat. Am. J. Pharm. 2012, 31, 152-155.

47. Rodrigues, K.A.D.F.; Amorim, L.V.; De Oliveira, J.M.G.; Noleto, C.; Moraes, D.F.C.; Andrade, E.H.A.; Maia, J.G.S.; Carneiro, S.M.P.; Carvalho, F.A.D.A. Eugenia uniflora L. Essential Oil as a Potential Anti-Leishmania Agent: Effects on Leishmania amazonensis and Possible Mechanisms of Action. Evid.-Based Complement. Altern. Med. 2013, 2013, 1-10. [CrossRef] [PubMed]

48. Figueiredo, P.L.B.; Pinto, L.C.; Da Costa, J.S.; Da Silva, A.R.C.; Mourão, R.; Montenegro, R.C.; Da Silva, J.; Maia, J.G.S. Composition, antioxidant capacity and cytotoxic activity of Eugenia uniflora L. chemotype-oils from the Amazon. J. Ethnopharmacol. 2019, 232, 30-38. [CrossRef] [PubMed]

49. Costa, D.P.; Filho, E.D.G.A.; Silva, L.M.A.; Santos, S.D.C.; Passos, X.S.; Silva, M.D.R.R.; Seraphin, J.C.; Ferri, P.H. Influence of fruit biotypes on the chemical composition and antifungal activity of the essential oils of Eugenia uniflora leaves. J. Braz. Chem. Soc. 2010, 21, 851-858. [CrossRef]

50. Melo, R.M.; Corrêa, V.F.S.; Amorim, A.C.L.; Miranda, A.L.P.; Rezende, C.M. Identification of impact aroma compounds in Eugenia uniflora L. (Brazilian Pitanga) leaf essential oil. J. Braz. Chem. Soc. 2007, 18, 179-183. [CrossRef]

51. Lago, J.H.G.; Souza, E.D.; Mariane, B.; Pascon, R.; Vallim, M.A.; Martins, R.C.C.; Baroli, A.A.; Carvalho, B.A.; Soares, M.G.; Santos, R.T.; et al. Chemical and Biological Evaluation of Essential Oils from Two Species of Myrtaceae - Eugenia uniflora L. and Plinia trunciflora (O. Berg) Kausel. Molecules 2011, 16, 9827-9837. [CrossRef] [PubMed]

52. Amorim, A.C.L.; Lima, C.K.F.; Hovell, A.M.C.; Miranda, A.L.P.; Rezende, C.M. Antinociceptive and hypothermic evaluation of the leaf essential oil and isolated terpenoids from Eugenia uniflora L. (Brazilian Pitanga). Phytomedicine 2009, 16, 923-928. [CrossRef]

53. Gallucci, S.; Neto, A.P.; Porto, C.; Barbizan, D.; Costa, I.; Marques, K.; Benevides, P.; Figueiredo, R. Essential Oil of Eugenia uniflora L.: An Industrial Perfumery Approach. J. Essent. Oil Res. 2010, 22, 176-179. [CrossRef]

54. Costa, D.P.; Santos, S.D.C.; Seraphin, J.C.; Ferri, P.H. Seasonal variability of essential oils of Eugenia uniflora leaves. J. Braz. Chem. Soc. 2009, 20, 1287-1293. [CrossRef]

55. Maia, J.G.S.; Andrade, E.H.A.; Da Silva, M.H.L.; Zoghbi, M.G.B. A new chemotype of Engenia uniflora L. from North Brazil. J. Essent. Oil Res. 1999, 11, 727-729. [CrossRef]

56. Victoria, F.N.; de Siqueira Brahm, A.; Savegnago, L.; Lenardão, E.J. Involvement of serotoninergic and adrenergic systems on the antidepressant-like effect of E. uniflora L. leaves essential oil and further analysis of its antioxidant activity. Neurosci. Lett. 2013, 544, 105-109. [CrossRef]

57. Victoria, F.N.; Lenardão, E.J.; Savegnago, L.; Perin, G.; Jacob, R.G.; Alves, D.; Da Silva, W.P.; Motta, A.D.S.D.; Nascente, P.D.S. Essential oil of the leaves of Eugenia uniflora L.: Antioxidant and antimicrobial properties. Food Chem. Toxicol. 2012, 50, 2668-2674. [CrossRef] [PubMed]

58. Mesquita, P.R.R.; Nunes, E.C.; Dos Santos, F.; Bastos, L.P.; Costa, M.A.; Rodrigues, F.D.M.; De Andrade, J.B. Discrimination of Eugenia uniflora L. biotypes based on volatile compounds in leaves using HS-SPME/GC-MS and chemometric analysis. Microchem. J. 2017, 130, 79-87. [CrossRef] 
59. Apel, M.A.; Limberger, R.P.; Sobral, M.; Henriques, A.T.; Ntalani, H.; Menut, C.; Bassiere, J.-M. Chemical Composition of the Essential Oils from Southern Brazilian Eugenia Species Part II. J. Essent. Oil Res. 2002, 14, 163-166. [CrossRef]

60. Nakamura, M.J.; Monteiro, S.S.; Bizarri, C.; Siani, A.C.; Ramos, M.F.D.S. Essential oils of four Myrtaceae species from the Brazilian southeast. Biochem. Syst. Ecol. 2010, 38, 1170-1175. [CrossRef]

61. Apel, M.A.; Sobral, M.; Henriques, A.T.; Menut, C.; Bessière, J.-M. Chemical Composition of the Essential Oils from Southern Brazilian Eugenia Species. Part IV: Section Racemulosae. J. Essent. Oil Res. 2002, 14, 290-292. [CrossRef]

62. Apel, M.A.; Sobral, M.; Schapoval, E.; Henriques, A.T.; Menut, C.; Bessiere, J.-M. Chemical Composition of the Essential Oils of Eugenia hyemalis and Eugenia stigmatosa. Part VI: Section Biflorae. J. Essent. Oil Res. 2004, 16, 437-439. [CrossRef]

63. Noleto-Dias, C.; Alves, L.P.L.; Rodrigues, K.A.D.F.; Brito, M.C.A.; Rosa, C.D.S.; Amaral, F.M.M.D.; Monteiro, O.D.S.; Andrade, E.H.D.A.; Maia, J.G.S.; Moraes, D.F.C. Chemical Composition and Larvicidal Activity of Essential Oils Extracted from Brazilian Legal Amazon Plants against Aedes aegypti L. (Diptera: Culicidae). Evidence-Based Complement. Altern. Med. 2015, 2015, 1-8. [CrossRef]

64. Souza, A.D.; Lopes, E.M.C.; Silva, M.C.D.; Cordeiro, I.; Young, M.C.M.; Sobral, M.E.G.; Moreno, P.R.H. Chemical composition and acetylcholinesterase inhibitory activity of essential oils of Myrceugenia myrcioides (Cambess.) O. Berg and Eugenia riedeliana O. Berg, Myrtaceae. Rev. Bras. Farmacogn. 2010, 20, 175-179. [CrossRef]

65. Mora, F.D.; Avila, J.L.; Rojas, L.B.; Ramírez, R.; Usubillaga, A.; Segnini, S.; Carmona, J.; Silva, B. Chemical composition and larvicidal activity of Eugenia triquetra essential oil from Venezuelan Andes. Nat. Prod. Commun. 2010, 5, 1934578-1000500633. [CrossRef]

66. Siani, A.C.; Souza, M.C.; Henriques, M.; Ramos, M.F.D.S. Anti-inflammatory activity of essential oils from Syzygium cumini and Psidium guajava. Pharm. Boil. 2013, 51, 881-887. [CrossRef]

67. Dias, C.N.; Rodrigues, K.A.F.; Carvalho, F.A.A.; Carneiro, S.M.P.; Maia, J.G.S.; Andrade, E.H.A.; Moraes, D.F.C. Molluscicidal and Leishmanicidal Activity of the Leaf Essential Oil of Syzygium cumini (L.) Skeels from Brazil. Chem. Biodivers 2013, 10, 1133-1141. [CrossRef] [PubMed]

68. Pereira, N.L.; Aquino, P.E.; Júnior, J.G.; Cristo, J.S.; Filho, M.A.V.; Moura, F.F.; Ferreira, N.M.; Silva, M.K.; Nascimento, E.M.; Correia, F.M.; et al. Antibacterial activity and antibiotic modulating potential of the essential oil obtained from Eugenia jambolana in association with led lights. J. Photochem. Photobiol. B Boil. 2017, 174, 144-149. [CrossRef] [PubMed]

69. Sobral-Souza, C.E.; Leite, N.F.; Da Cunha, F.A.B.; Pinho, A.I.; Albuquerque, R.S.; Carneiro, J.N.; Menezes, I.R.; Da Costa, J.G.M.; Franco, J.L.; Coutinho, H.D.M. Cytoprotective effect against mercury chloride and bioinsecticidal activity of Eugenia jambolana Lam. Arab. J. Chem. 2014, 7, 165-170. [CrossRef]

70. Machado, R.R.P.; Jardim, D.F.; Souza, A.R.; Scio, E.; Fabri, R.L.; Carpanez, A.G.; Grazul, R.M.; de Mendonça, J.P.R.F.; Lesche, B.; Aarestrup, F.M. The effect of essential oil of Syzygium cumini on the development of granulomatous inflammation in mice. Rev. Bras. Farmacogn. 2013, 23, 488-496. [CrossRef]

71. Siebert, D.A.; Tenfen, A.; Yamanaka, C.N.; De Cordova, C.M.M.; Scharf, D.R.; Simionatto, E.; Alberton, M.D. Evaluation of seasonal chemical composition, antibacterial, antioxidant and anticholinesterase activity of essential oil from Eugenia brasiliensis Lam. Nat. Prod. Res. 2014, 29, 289-292. [CrossRef]

72. Lima, N.P.; Cerqueira, S.H.F.; Fávero, O.A.; Romoff, P.; Lago, J.H.G. Composition and Chemical Variation of the Essential Oil from Leaves Of Eugenia brasiliensis Lam. And Eugenia sp. (Myrtaceae). J. Essent. Oil Res. 2008, 20, 223-225. [CrossRef]

73. Da Costa, J.S.; Barroso, A.S.; Mourão, R.H.V.; da Silva, J.K.R.; Maia, J.G.S.; Figueiredo, P.L.B. Seasonal and Antioxidant Evaluation of Essential Oil from Eugenia uniflora L., Curzerene-Rich, Thermally Produced in Situ. Biomolecules 2020, 10, 328. [CrossRef]

74. Rezende, W.P.; Borges, L.L.; Alves, N.M.; Ferri, P.H.; Paula, J.R. Chemical variability in the essential oils from leaves of Syzygium jambos. Rev. Bras. de Farm. 2013, 23, 433-440. [CrossRef]

75. Saleem, M.; Nazir, M.; Ali, M.S.; Hussain, H.; Lee, Y.S.; Riaz, N.; Jabbar, A. ChemInform Abstract: Antimicrobial Natural Products: An Update on Future Antibiotic Drug Candidates. Chemin 2010, 41, $238-254$. [CrossRef] 
76. Barbosa, L.N.; Probst, I.D.S.; Andrade, B.F.M.T.; Alves, F.C.B.; Albano, M.; Cunha, M.; Doyama, J.T.; Rall, V.L.; Junior, A.F. In vitro Antibacterial and Chemical Properties of Essential Oils Including Native Plants from Brazil against Pathogenic and Resistant Bacteria. J. Oleo Sci. 2015, 64, 289-298. [CrossRef]

77. Medeiros, J.; Medeiros, N.; Medeiros, H.; Davin, L.B.; Lewis, N.G. Composition of the Bioactive Essential Oils from the Leaves of Eugenia stipitata McVaugh ssp. sororia from the Azores. J. Essent. Oil Res. 2003, 15, 293-295. [CrossRef]

78. Becker, N.A.; Volcão, L.M.; Camargo, T.M.; Freitag, R.A.; Ribeiro, G.A. Biological properties of Eugenia uniflora L. essential oil: Chemical composition and antimicrobial activity. VITTALLE Revista de Ciências da Saúde 2017, 29, 22-30. [CrossRef]

79. Bhattacharjee, A. Anticholinesterase potential of phytoextracts and their bioactive compounds: A promising therapeutic agent against Alzheimer's disorder. MOJ Tumor Res. 2018, 1, 83-87. [CrossRef]

80. Ayaz, M.; Sadiq, A.; Junaid, M.; Ullah, F.; Subhan, F.; Ahmed, J. Neuroprotective and Anti-Aging Potentials of Essential Oils from Aromatic and Medicinal Plants. Front. Aging Neurosci. 2017, 9, 168. [CrossRef] [PubMed]

81. Angelini, P.; Tirillini, B.; Akhtar, M.S.; Dimitriu, L.; Bricchi, E.; Bertuzzi, G.; Venanzoni, R. Essential Oil with Anticancer Activity: An Overview. In Anticancer Plants: Natural Products and Biotechnological Implements; Springer Science and Business Media LLC: Berlin/Heidelberg, Germany, 2018; Volume 2, pp. 207-231.

82. Kaiser, M.; Mäser, P.; Tadoori, L.P.; Ioset, J.-R.; Brun, R. Antiprotozoal Activity Profiling of Approved Drugs: A Starting Point toward Drug Repositioning. PLoS ONE 2015, 10, e0135556. [CrossRef]

83. Xu, D.-P.; Li, Y.; Meng, X.; Zhou, T.; Zhou, Y.; Zheng, J.; Zhang, J.-J.; Li, H.-B. Natural Antioxidants in Foods and Medicinal Plants: Extraction, Assessment and Resources. Int. J. Mol. Sci. 2017, 18, 96. [CrossRef]

84. Monzote, L.; Alarcón, O.; Setzer, W.N. Antiprotozoal activity of essential oils. Agric. Consp. Sci. 2012, 77, 167-175.

85. Tan, B.L.; Norhaizan, M.E.; Liew, W.-P.-P.; Rahman, H.S. Antioxidant and Oxidative Stress: A Mutual Interplay in Age-Related Diseases. Front. Pharmacol. 2018, 9, 1-28. [CrossRef]

86. Mimica-Dukić, N.; Orčić, D.; Lesjak, M.; Šibul, F.; Zheljazkov, V.; Cantrell, C.L. Essential Oils as Powerful Antioxidants: Misconception or Scientific Fact? In ACS Symposium Series; American Chemical Society (ACS): Washington, DC, USA, 2016; Volume 1218, pp. 187-208.

87. Yousefi, M.; Rahimi-Nasrabadi, M.; Pourmortazavi, S.M.; Wysokowski, M.; Jesionowski, T.; Ehrlich, H.; Mirsadeghi, S. Supercritical fluid extraction of essential oils. TrAC Trends Anal. Chem. 2019, 118, 182-193. [CrossRef]

88. Victoria, F.; Anversa, R.; Savegnago, L.; Lenardão, E. Essential oils of E. uniflora leaves protect liver injury induced by acetaminophen. Food Biosci. 2013, 4, 50-57. [CrossRef]

89. Arruda, R.D.C.D.O.; Victório, C.P. Leaf Secretory Structure and Volatile Compounds of Eugenia copacabanensis Kiaersk. (Myrtaceae). J. Essent. Oil Res. 2011, 23, 1-6. [CrossRef]

90. Franco, M.R.B.; Shibamoto, T. Volatile Composition of Some Brazilian Fruits: Umbu-caja (Spondias citherea), Camu-camu (Myrciaria dubia), Araça-boi (Eugenia stipitata), and Cupuaçu (Theobroma grandiflorum). J. Agric. Food Chem. 2000, 48, 1263-1265. [CrossRef] [PubMed]

91. Fajardo-Oliveros, A.; Morales Pérez, A.L. Composition of arazá (Eugenia stipitata McVaugh) seed essential oil. Momentos Cienc. 2011, 8, 126-130.

92. Santos, F.R.; Braz-Filho, R.; Castro, R.N. Influência da idade das folhas de Eugenia uniflora L. na composição química do óleo essencial. Quim. Nova 2015, 38, 762-768. [CrossRef]

93. Scharf, D.R.; Simionatto, E.; Kassuya, C.A.L.; Stefanello, M.; Élida, A. Essential Oil from Eugenia jambolana Seeds: Chemical Composition and Changes During Storage. J. Essent. Oil Bear. Plants 2016, 19, 2077-2082. [CrossRef]

(C) 2020 by the authors. Licensee MDPI, Basel, Switzerland. This article is an open access article distributed under the terms and conditions of the Creative Commons Attribution (CC BY) license (http://creativecommons.org/licenses/by/4.0/). 